\title{
ОПРЕДЕЛЕНИЕ ГРАНИЦ ГОРОДСКИХ АГЛОМЕРАЦИЙ РОССИИ: СОЗДАНИЕ МОДЕЛИ И РЕЗУЛЬТАТЫ
}

\author{
АЛЕКСАНДР РАЙСИХ
}

\begin{abstract}
Статья является продолжением статьи (Райсих 2020), где была сформулирована проблема определения границ городских агломераџий или делимитаџии городских агломераций, исходя из мирового опыта. При этом было подчеркнуто, что методика оченки границ городских агломераций должна быть основана, с одной стороны, на доступных для всех стран исходных данных, а с другой - на накопленном мировом опыте с обеспечением приемлемого приближения ко многим уже применяемым моделям делимитации.
\end{abstract}

Целью настоящей статьи является выработка и апробаџия модели делимитации городских агломераций, основанной на международном и отечественном опьте и подходящей для условий России и иньхх стран мира.

На основании доступных данных были проанализированы результаты применения различных методик делимитации городских агломераций, выявлень их преимущества и недостатки. В итоге была предложена авторская модель делимитаџии городских агломераций. Сделанная на ее основании оценка состава и грании городских агломераџий России показала достаточно высокую степень приближения к уже существующим моделям делимитаџии городских агломераций (которые, как правило, построены на использовании исходных данных, не оцениваемых статистическими органами большинства стран мира, включая Россию).

Ключевые слова: городская агломерация, делимитация городских агломераций, ядро агломерации, урбанизированный ареал, метрополитенский ареал, объединенный метрополитенский ареал.

В России 42\% населения проживают в городах, насчитывающих свыше 250 тыс. жителей, и еще $17 \%$ проживают в зонах функционального влияния этих городов ${ }^{1}$. Таким образом, около 60\% общего числа жителей страны сосредоточены на этих высокоурбанизированных территориях.

В настоящее время становится необходимым комплексное развитие таких территорий, называемых городскими агломерациями. Прилегающие к крупным городам территории с расположенными на них поселениями - наиболее подготовленный для градостроительного освоения резерв, что объясняется близостью социальноэкономических ресурсов города-центра, развитостью сети инженерных и транспортных коммуникаций, сохранившимися пространственными резервами роста и др. (Малоян 2012).

АЛЕКСАНДР ЭДУАРДОВИч РАЙСИХ (reisig@mail.ru), НЕЗАВИСИМЫЙ ЭКСПЕРТ, РОССИЯ.

СТАТЬЯ ПОСТУПИЛА В РЕДАКЦИЮ В МАЕ 2020 Г.

\footnotetext{
${ }^{1}$ Оценка автора на основе методики оценки метрополитенских ареалов, изложенной в данной статье и данных (Росстат 2020).
} 
В зарубежных странах применяются различные понятия и методики, определяющие понятия «городские агломерации». Но их можно четко структурировать по применению двух основных подходов, можно сказать, двухэтапного подхода к определению городских агломераций:

1) морфологического для выделения ядра агломерации - непрерывной зоны населенных пунктов (или частей населенных пунктов);

2) функционального для выделения всей городской агломерации, определяемой как область взаимодействия между ядром агломерации и периферией агломерации (т.е. остальной области городской агломерации за исключением ее ядра), состоящей из соседних муниципалитетов (частей муниципалитетов), которые демонстрируют значительную взаимосвязь с ядром.

Ранее условились (Райсих 2020), что для различения ядра агломерации и всей городской агломерации будем использовать наиболее распространенные термины урбанизированный ареал (УА) для ядра агломерации и метрополитенский ареал (МА) для городской агломерации.

До недавнего времени термин «городские агломерации» в нормативно-правовых актах России не был определен. С принятием Стратегии пространственного развития Российской Федерации на период до 2025 г. $^{2}$ было введено два термина городских агломераций: крупные и крупнейшие городские агломеращии. К первым относится «совокупность компактно расположенных населенных пунктов и территорий между ними с общей численностью населения 500 mыс. человек - 1000 mыс. человек, связанных совместным использованием инфраструктурных объектов и объединенных интенсивными экономическими, в том числе трудовыми, и сочиальными связями», а ко вторым - то же самое, только с общей численностью населения свыше 1 млн человек. Можно заметить, что приведенные определения опираются на функциональный подход, но, в отличие от определений близких к ним метрополитенских статистических ареалов (MSA) США или функциональных урбанизированных ареалов (FUA) Евросоюза ${ }^{3}$, не содержат в себе количественных критериев маятниковой трудовой миграции (МТМ). Но это и понятно официальная статистика по МТМ в России отсутствует.

Основная проблема в определении городских агломераций состоит не в поиске приемлемого определения того, что такое городская агломерация, является ли определенное скопление населенных пунктов городской агломерацией, а в критериях определения границ городских агломераций, основанных на объективных, доступных критериях и показателях. Как объект градостроительного проектирования агломерация должна иметь границы, соответствующие цели ее создания как комплексообразующей системы (Малоян 2012).

\footnotetext{
2 Утверждена распоряжением Правительства Российской Федерации №207-р от 13 февраля 2019 г. URL: http://static.government.ru/media/files/UVAlqUtT08o60RktoOX122JjAe7irNxc.pdf

${ }^{3}$ Подробно о методах расчета MSA и FUA см. (Райсих 2020).
} 
Государствами применяются различные критерии делимитации урбанизированных ареалов (УА) (Райсих 2020):

1) критерий минимально допустимой плотности населения - включаются смежные ячейки квадратной или квартальной ${ }^{4}$ сетки с плотностью выше предельной (Швейцария, Евросоюз в целом по европейским странам, а также в странах, применяющих еще и критерий максимально допустимых разрывов по автодорогам);

2) критерий максимально допустимых разрывов между зданиями - измеряется расстояние по прямой линии (скандинавские страны, Англия и Уэльс, Франция);

3) критерий максимально допустимых разрывов между застройкой вдоль автодорог определяются минимальные разрывы между границами застройки вдоль нескольких вариантов автодорог (США, Канада, Австралия).

Необходимо отметить, что основная трудность в применении критериев делимитации УА к российским городам состоит в отсутствии статистических данных по жилым районам и кварталам крупных городов численностью хотя бы 5-10 тыс. человек, которые могут являться строительными блоками для формирования УА. Административные районы крупных российских городов, за исключением Москвы и Санкт-Петербурга, построены, как правило, по секторальному принципу с примерно равной численностью населения от 100 до 300 тысяч человек. Население небольших удаленных районов города при этом не выделяется. Этим можно объяснить практически полное отсутствие работ по делимитации УА среди отечественных исследователей. При этом делимитация городских агломераций (МА) в работах отечественных ученых определяется исходя из изучения функциональных зависимостей центрального города в административных границах, а не урбанизированного ареала, с периферией агломерации (Райсих 2020).

\section{КРИТЕРИИ ДЕЛИМИТАЦИИ ГОРОДСКИХ АГЛОМЕРАЦИЙ, ПРЕДЛОЖЕННЫЕ ОТЕЧЕСТВЕННЫМИ УЧЕНЫМИ}

Советскими и российскими учеными проведены многочисленные исследования вопросов, связанных с делимитацией метрополитенских ареалов (MA), базирующиеся на применении функционального подхода к городским агломерациям. В рамках этого подхода можно выделить следующие основные критерии делимитации МА:

1) интенсивности маятниковой трудовой миграции (МТМ);

2) транспортной доступности;

3) гравитационный.

Критерий интенсивности МТМ, как было показано ранее (Райсих 2020), фактически является единственным применяемым зарубежными статистическими ведомствами для

\footnotetext{
${ }^{4}$ Ограниченные дорогами или природными объектами кварталы застройки.
} 
делимитации МА. Для включения административной единицы в МА необходимо ее соответствие прямому ${ }^{5}$ или обратному критерию маятниковой миграции.

В России широкое применение критерия интенсивности МТМ пока невозможно изза отсутствия сколько-нибудь реальных (и публикуемых) статистических данных. Определенную информацию, по-видимому, сможет предоставить предстоящая всероссийская перепись населения 2020 г. В ее утвержденных бланках впервые с 1970 г. появилась серия вопросов о трудовой маятниковой миграции 7.

C опубликованием результатов переписи (ориентировочно в 2023 г.) у широкого круга исследователей появятся первичные статистические данные, в том числе для делимитации городских агломераций по критерию интенсивности МТМ. Пока же работы отечественных исследователей по данному вопросу связаны с оценкой величины МТМ по отдельным российским агломерациям замещающими методами.

Так, Ю.Ю. Шитова и Ю.А. Шитов (2016) оценивали величину МТМ Московской агломерации как результат миллионов индивидуальных передвижений от места жительства до места работы, которые в свою очередь определялись на основе информации по ИНН работодателей по данным пенсионного фонда РФ, налоговой службы и реестров по российским фирмам и компаниям. А.Г. Уляева, Л.И. Мигранова (2017) при оценке Уфимской агломерации скорректировали оценку трудовых мигрантов, вычитая из численности трудоспособного населения среднегодовую численность работников организаций, числа женщин, находящихся в декретном отпуске (условно приравнивая к численности детей, родившихся в текущем году), числа потенциальных студентов (условно - население от 18 до 23 лет), число занятых в малом и среднем бизнесе, безработных и численности убывшего населения трудоспособного возраста (последнее рассчитывалось, исходя из доли убывших в суммарном населении).

К Московскому урбан-форуму 2017 была проведена оценка ряда агломераций на основе анализа больших данных (Big Data) ${ }^{8}$ В качестве критерия были использованы данные мобильных операторов "большой тройки" («Билайн», «МТС», «Мегафон») о биллинге абонентов. Авторы методики определяли границы агломераций Москвы, СанктПетербурга, Екатеринбурга, Новосибирска, Казани и еще ряда городов по критерию 15\% прямой миграции, но не указали период замеров (вероятно, не меньше недели). В результате площадь Московской агломерации получилась равной 26 тыс. км ${ }^{2}$, затронув даже восток Смоленской области и тем самым многократно превышая по площади любую другую сопоставимую по населению агломерацию в мире (Шанхай, Лондон, Париж, НьюЙорк, Токио).

\footnotetext{
${ }^{5}$ Минимально допустимая доля трудоспособного населения административной единицы периферии агломерации, работающего в ядре агломерации или в остальных административных единицах агломерации. ${ }^{6}$ Минимально допустимая доля рабочих мест в составе административной единицы периферии агломерации, на которых работают жители других административных единиц агломерации.

${ }^{7}$ URL: https://gks.ru/storage/mediabank/rasp08112019-\%202648-\%D1\%80.pdf (дата обращения 12.05.2020).

${ }^{8}$ Акишин А. (2017). 3 часа на дорогу до работы: исследование московской агломерации. URL: https://zen.yandex.ru/media/strelkamag.com/3-chasa-na-dorogu-do-raboty-issledovanie-moskovskoi-aglomeracii5a149944865165a7e788fbc4 (дата обращения 12.05.2020).
} 
А.Г. Махрова и Р.А. Бабкин (2018) с использованием аналогичных данных провели оценку фактического населения Москвы и пригородов в летний / осенний выходной / рабочий день в рабочее / нерабочее время по четырем зонам в городе и четырем в области в зависимости от удаленности от центра, а также по четырем секторам пригородной зоны (север, восток, юг, запад). Для делимитации городских агломераций здесь может представлять интерес выявленная картина миграций': первый (ближайший) пояс Московской области и новой Москвы характеризуется существенными суточными колебаниями МТМ (17\%), второй пояс - превышением недельных колебаний МТМ над суточными (18-27\% против 11\%), третий пояс - еще большими недельными колебаниями MTM (35\%) и огромными сезонными (75\%) и почти незаметными суточными (5\%), четвертый пояс - ослабеванием всех видов пульсаций (26\% - сезонные, 25\% - недельные, $3 \%$ - суточные). Соответственно, муниципалитеты с похожей картиной МТМ могут включаться в тот или иной пояс агломерации.

Ю.Ю. Шитова, Ю.А. Шитов, В.В. Власов (2019) также на основании данных «большой тройки» мобильных операторов о биллинге абонентов провели оценку потерь времени при пользовании общественным транспортом в Московской агломерации в зависимости от удаленности от центра Москвы, времени и дня недели поездки, что может применяться для определения границ Московской агломерации.

Критерий транспортной доступности считался основным до сбора статистическими ведомствами информации о величинах МТМ. Он состоит в определении изохрон времени доступности от центра агломерации, т. е. линии, соединяющей точки на земле с одинаковой временной доступностью от центра (агломерации). В СССР, а потом в России, этот метод получил наиболее широкое распространение.

В СССР были разработаны две основные методики по делимитации городских агломераций с помощью этого критерия: 1) методика Института географии АН СССР; 2) методика ЦНИИП градостроительства.

Методика института географии (ИГ) АН СССР (Лаппо 1978) состоит из следующих этапов: 1) последовательно в порядке уменьшения населения отбираются города с населением не менее 250 тыс. человек - кандидаты на ядра агломераций; 2) определяются города и поселки городского типа (пгт) в пределах 2-часовой доступности от ядра агломерации и в пределах 0,5-часовой доступности от больших и средних городов на периферии городской агломерации; 3) проверяются на развитость агломерации по коэффициенту развитости

$$
K_{\text {разв }}=P^{*}\left(M^{*} m+N^{*} n\right),
$$

где $P$ - людность городской агломерации, млн чел. ${ }^{10} ; M$ и $N$ - количество городов и пгт соответственно; $m$ и $n$ - доли в суммарной численности населения агломерации городов и пгт соответственно.

\footnotetext{
${ }^{9}$ Авторы критерии делимитации не предлагали.

${ }^{10}$ Под «людностью городской агломерации» авторы методики понимают численность населения главных городов агломерации, превышающих 250 тыс. человек.
} 


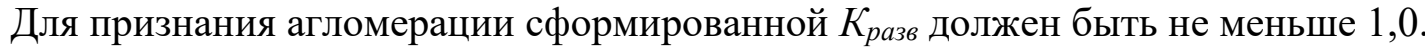

Одно из очень уязвимых мест в этой методике, по нашему мнению, связано с использованием статуса населенного пункта. Поселки городского типа (пгт) в постсоветское время массово и по-разному в различных регионах страны переводились в сельские населенные пункты. При этом нормативно установленные критерии, что есть город, а что - пгт, в России отсутствуют. Так, численность населения самого крупного (на 1 января 2020 г.) сельского населенного пункта (станица Каневская, Краснодарский край) составляет 44 тыс. жителей (44,4 тыс. человек по данным Всероссийской переписи населения 2010 г. (Росстат 2010), 44,0 тыс. человек - оценка на 1 января 2020 г.), численность населения самого маленького города - 405 жителей (Иннополис в Татарстане) (Росстат 2020), а пгт - еще меньше.

На этот недостаток обращали внимание и сами авторы методики (Лаппо, Полян, Селиванова 2007). Представляется, что возможно оценивать развитость агломераций через категорию «населенный пункт» (вместо город или пгт) или, что еще лучше, через категорию урбанизированных ареалов (УА). К примеру, вместо городов учитывать УА численностью населения свыше 20 тыс. жителей, а вместо пгт - УА численностью от 5 до 20 тыс. жителей. Таким образом, получится усовершенствованная методика оценки развитости агломераций, не зависящая от статуса и границ населенных пунктов.

Методика ЦНИИП градостроительства (Листенгурт 1975) схожа с методикой ИГ АН СССР, но вместо коэффициента развитости для проверки состоятельности агломерации используются коэффициент агломеративности (отношение плотности сети городских поселений к среднему кратчайшему расстоянию между ними) и индекс агломеративности (отношение численности городского населения внешней зоны к городскому населению всей агломерации). Кроме того, не используются 0,5-часовые изохроны от городов на периферии агломерации.

На основе этих двух методик П.М. Полян, И.Н. Заславский и Н.И. Наймарк (1988) предложили унифицированную методику делимитации городских агломераций, состоящую из следующих этапов: 1) отбираются города - потенциальные центры агломераций с численностью населения свыше 100 тыс. человек; 2) устанавливается зона потенциального действия агломерационных связей: 2-часовая (брутто) изохрона транспортной доступности центра, совмещенная с 0,5-часовой изохроной от больших и средних городов, расположенных на периферии; 3) если при этом во внешней зоне окажется не менее двух городских поселений и система успешно преодолеет тест на развитость

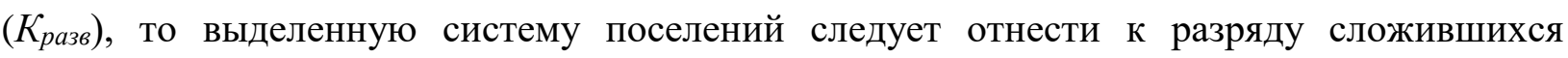
городских агломераций.

Необходимо отметить, что задача оценки развитости агломераций, применяемая в описанных выше методиках, во многих исследованиях если и рассматривается, то рассматривается как второстепенная по отношению к задаче делимитации городских агломераций (Пузанов, Попов 2017). На наш взгляд, тут нет противоречий: первоначально должна быть проведена делимитация городских агломераций по объективным критериям морфологического и (или) функционального подхода - т. е. надо определить, какие границы должны быть при прочих равных условиях, а не императивно задавать границы 
административным подходом. Тогда и сравнение агломераций по их развитости, выявление дисбалансов развития различными методами и с использованием различных показателей, прежде всего, экономических ${ }^{11}$, будет объективнее.

Российскими учеными при оценке отдельных агломераций использовались различные методы. А.И. Стрельников, О.С. Семенова (2010) осуществляли оценку границ Красноярской агломерации путем замеров интенсивности транспортного движения различными видами транспорта между населенными пунктами агломерации в период пиковой маятниковой миграции и определяли границы агломерации в местах резкого падения интенсивности движения.

Делимитация границ Екатеринбургской агломерации, проведенная Н.Р. Ижгузиной (2014), осуществлялась путем первоначальной оценки границ по 0,5-, 1-, 1,5- и 2-часовым изохронам, причем время было переведено в расстояние, исходя из средней скорости движения 75 км/ч, а затем на основе изучения интенсивности движения общественного транспорта была выбрана 1-часовая изохрона. Подобную методику для Уфимской агломерации применила А.Г. Уляева (2016), когда оценивала время транспортной доступности для районов, проверяемых на включение в агломерацию, как отношение среднего расстояния от ядра агломерации до центра района и от ядра агломерации до наиболее отдаленного поселения района к средней скорости движения на автомобиле.

Серьезную работу по определению границ городской агломерации на примере Санкт-Петербурга провели М.Е. Монастырская и О.А. Песляк (2019). Границы агломерации устанавливались по границам муниципальных образований и определялись последовательно по четырем методам:

1) по критерию транспортной доступности: от 60 - 90 - 120 минут соответственно;

2) по критерию слитности застройки (морфологический критерий): $200-250-500$ метров расстояние между застройкой соответственно, при этом к застроенным территориям относили жилые и промышленные территории, парки, сады, скверы, кладбища, аэропорты, дороги, водные объекты, берега которых сообщаются друг с другом посредством мостов или паромов;

3) по «демографическому» критерию - по плотности расселения, превышающей среднюю величину плотности муниципального образования и без разрывов;

4) на основе функциональных связей (изучение маятниковой миграции) - включаются муниципальные образования, более 10\% численности населения которых являются трудовыми маятниковыми мигрантами ${ }^{12}$.

\footnotetext{
${ }^{11}$ Наиболее полный анализ методик оценки развитости агломераций с предложением собственной методики, включая индикаторы дисбаланса, и апробированием на 4 российских агломерациях проведен Институтом экономики города (Пузанов, Попов 2017).

12 Так как официальные данные о доле маятниковых трудовых мигрантов отсутствуют, авторы оценивали ее на основе двух первичных данных из следующих (каких - не указано): 1) официальных деперсонализированных данных государственных органов власти (Пенсионный фонд РФ, Федеральная налоговая служба) об официальной регистрации граждан и официальном месте работы; 2) данных социологических опросов; 3) данных о количестве отправленных пассажиров по железнодорожным станциям пригородных направлений железной дороги; 4) данных о локализации активности в сетях
} 
Отметим в данной работе смешение всех перечисленных выше используемых подходов и критериев: 1 и 4 - это функциональный подход, описывающий агломерацию, т.е. МА, включающий ядро агломерации и ее периферию, 2 и 3 - морфологический, описывающий только ядро агломерации, т. е. УА. Соответственно, площадь агломерации при применении морфологического подхода оказалась меньшей, чем при использовании функционального подхода.

Г.С. Юсин с коллегами (Юсин, Раев, Алексеева 2015) оценил количество российских агломераций численностью 100 тыс. человек и более, однако методика делимитации в тексте отсутствует, впрочем, как и состав агломераций (кроме 17 агломерациймиллионников). Состав приведенных в тексте агломераций-миллионников неясен (это тем более так, ибо не показана методика этого выделения): наличествует Владивостокская агломерация, в которую включена Находка, расположенная на расстоянии 180 км от Владивостока. При этом отсутствует Краснодар, только в городском округе которого более 1 млн жителей - и это без пригородов, образующих с Краснодаром слитную застройку.

Подход, основанный на критерии транспортной доступности, принят и в Обосновывающих материалах (Минэкономразвития 2018) к Стратегии пространственного развития Российской Федерации на период до 2025 г. ${ }^{13}$ Крупные агломерации в Стратегии были определены как агломерации с численностью населения в центральном городе (ядре) не менее 500 тыс. человек и транспортной доступностью от окраин городской агломерации до ее ядра 1,5 часа (2 часа - для Московской и Петербургской агломераций). Приведен был состав агломераций и их визуализация.

Е.В. Антонов и А.Г. Махрова (2019) осуществили делимитацию границ с их визуализацией для крупных российских агломераций свыше 500 тыс. жителей по четырем вариантам:

1) минимальный, когда в состав агломерации включаются только муниципальные образования (МО), граничащие с ядром агломерации;

2) базовый, исходя из локализации большей части населения МО в пределах 2-часовой изохроны транспортной доступности от ядра ${ }^{14}$;

3) расширенный, исходя из локализации хотя бы части населения МО в пределах 2часовой изохроны транспортной доступности от ядра;

4) максимальный - по экономическим микрорайонам (ЭМР) Е.Е. Лейзеровича (Лейзерович 2010).

Варианты 2 и 3 характеризуют применение критерия транспортной доступности. Вариант 1 формально можно отнести к морфологическому подходу, хотя он применяется к

мобильной связи; 5) данных геопространственной привязки информации из социальных сетей и интернетприложений.

13 Утверждена распоряжением Правительства Российской Федерации № 207-р от 13 февраля 2019 г. URL: http://static.government.ru/media/files/UVAlqUtT08o60RktoOX122JjAe7irNxc.pdf

${ }^{14}$ Получившиеся границы агломераций, за небольшими исключениями, соответствуют границам агломераций, указанных в Обосновывающих материалах Стратегии пространственного развития на период до 2025 г. (Минэкономразвития 2018). 
скоплениям зданий, а не к МО, и из-за больших площадей МО его применение даёт очень противоречивые результаты. Делимитация границ агломераций по экономическим микрорайонам (вариант 4), на наш взгляд, методологически не обоснована, так как ЭМР покрывают всю территорию страны и являются зонами преимущественного влияния центра агломерации вне зависимости от расстояния до ядра. Соответственно, сомнению может быть подвергнут вывод, что они являются аналогами американских MSA. Заметим, правда, что Московский ЭМР Лейзеровича существенно меньше 2-часовой изохроны, и его границы находятся между минимальным и базовым вариантами.

Резюмируя, необходимо отметить некоторые недостатки использования критерия транспортной доступности для делимитации городских агломераций:

- параметры интенсивности движения и среднего времени передвижения на общественном транспорте - по многим городам сложно найти актуальные расписания и, следовательно, правильно их оценить;

- при оценке среднего времени передвижения на личном автотранспорте большое значение приобретает скорость движения на автодорогах вследствие пробок;

- оценка в минутах/часах на преодоление одного и того же расстояния может существенно отличаться для агломераций в разных странах и частей одной страны изза недоучета ряда дорог в платформах «Яндекс.Карты» или «Google.Maps». Поэтому для широкого применения методики делимитации к агломерациям разных стран эффективнее использовать расстояние;

- дискретность методики, характеризующаяся скачкообразным увеличением размеров агломерации в случае роста населения ядра агломерации сверх порогового уровня.

Гравитационный критерий состоит в применении к делимитации городских агломераций гравитационной модели Рейли-Конверса (Лимонов 2014: 133). В ней сила взаимодействия жителей периферийной зоны с центром притяжения (ядро) уменьшается в степенной зависимости по мере удаления от центра притяжения. При достижении определенного предельного расстояния, рассчитываемого от центра (центральной точки) агломерации, сила притяжения ядра городской агломерации уже будет не столь существенной и агломерационный эффект практически перестанет действовать. Поэтому можно считать, что любые точки, расположенные дальше этого предельного расстояния, уже не входят в агломерацию. Таким образом, итоговая модель зависимости имеет следующий вид:

$$
L_{j}=\sqrt[v]{x * P_{j}} \text { или } L_{j}=k * \sqrt[v]{N_{j}}
$$

где $L_{j}$ - предельное расстояние агломерации, км; $P_{i}, N_{j}=P_{j} / 1000$ - население урбан-ареала (или главного города) $j$, образующего метро-ареал, чел. и тыс. чел. соответственно; х, $k-$ коэффициенты; $v$ - показатель степени.

Показатель степени $v$ может принимать различные значения для различных задач: исторически $v=2$ из формулы закона всемирного тяготения, а например, в работе (Жиро 1960) $v=6$ для области выбора продуктов питания, $v=2,7$ для области выбора промышленных товаров (Занадворов, Занадворова 2003: 129). Применительно к нашей 
задаче можно говорить о допустимой области выбора места работы, исходя из места жительства и (или), наоборот, выбора места жительства, исходя из места работы.

Гравитационную модель для делимитации городских агломераций в зависимости от численности населения главного города агломерации при $v=3$ предлагали Ю.Л. Пивоваров (2002) по формуле (3) и С.Н. Соколов (2015) по формуле (4) применительно к агломерациям Ханты-Мансийского автономного округа - Югра.

$$
\begin{aligned}
& L_{j}=\sqrt[3]{P_{j} / 4} \text { или } L_{j}=6,3 * \sqrt[3]{N_{j}} \\
& L_{j}=\sqrt[3]{P_{j} / 2} \text { или } L_{j}=7,9 * \sqrt[3]{N_{j}}
\end{aligned}
$$

где $L_{j}$ - зона влияния города $j$, км; $P_{j}$ - население города $j$, чел.; $N_{j}$ - население города $j$, тыс. человек.

Ю.Л. Пивоваров исходил из оценки зон влияния в 25 км для смежных городов численностью населения 50 тыс. жителей и более. По такой формуле получается зона влияния для 1-миллионного города в 63 км, для 5-миллионного Санкт-Петербурга в 108 км, 12-миллионной Москвы в 144 км. На наш взгляд, для крупнейших городов размеры агломерации получаются слишком большими.

При применении формулы (4) С.Н. Соколова оказывается, что в Московскую агломерацию необходимо включать Тверь, Тулу и Калугу, а Рязань и Владимир - нет, что вызывает много вопросов.

В литературе встречалось предложение определять предельное расстояние агломерации, при котором плотность населения внутри окружности, очерчивающей агломерацию, составит 100 чел./км² 15 (Нефедова, Аверкиева, Махрова 2016: 52), что эквивалентно формуле:

$$
L_{j}=\sqrt[2]{P_{j} / 314} \text { или } L_{j}=1,78 * \sqrt[2]{N_{j}}
$$

При применении формулы (5) в агломерацию Москвы будут включены все 5 ближайших областных центров, а для города с населением 50 тыс. человек получится расстояние агломерации в 12 км, тогда как расстояние от центра до окраин многих таких городов больше.

На наш взгляд, гравитационный критерий может служить хорошим методом для проверки результатов применения различных критериев в разных странах. Исходя из площади $S_{j}$ агломерации $j$, можно рассчитать среднее предельное расстояние по прямой от центра агломерации $R_{j}$ и исследовать степенную зависимость среднего предельного расстояния от населения агломерации $Q_{j}$ :

$$
R_{j}=\sqrt[2]{S_{j} / \pi}=\sqrt[2]{(b / \pi) * \sqrt[w]{Q_{j}}}=k * \sqrt[v]{Q_{j}}
$$

где $S_{j}=b * \sqrt[w]{Q_{j}}-$ площадь агломерации $(\mathrm{MA}) j$, км, находящаяся в степенной зависимости

${ }^{15}$ Необходимо отметить, что учитывается население только главного города. 
от населения этой же агломерации (МА) $Q_{j}$, тыс. чел.; х, $k=\sqrt[2]{b / \pi}-$ коэффициенты; $w=$ $2 * v$ - показатели степени.

В заключение обзора критериев делимитации городских агломераций с применением функционального подхода хотелось бы отметить, что критерий интенсивности МТМ является предпочтительным к применению, когда есть официальные статистические данные о размерах маятниковой трудовой миграции из одного муниципалитета в другой. При их отсутствии применяют иные критерии: транспортной доступности и гравитационный. Однако в то время как критерий интенсивности МТМ показывает существующую картину взаимодействия, гравитационный и транспортной доступности - теоретическое оптимальное взаимодействие, важное для экономического, производственного и транспортного планирования, но не описывающее текущую (и возможно быстро меняющуюся) ситуацию. Таким образом, одновременное применение обоих методов (гравитационный или транспортной доступности и интенсивности МТМ) позволяет оценить существующие и перспективные проблемы и дисбалансы в формировании рынков труда, размещении социальных служб, исходя из транспортной доступности и др.

\section{ВЫБОР МОДЕЛИ ДЕЛИМИТАЦИИ УРБАНИЗИРОВАННОГО АРЕАЛА}

Исходя из поставленной цели определить доступную модель делимитации, дающую достаточно достоверные результаты, интересным, с практической точки зрения, видится опыт США по делимитации урбанизированных ареалов (Райсих 2020). На основании проанализированного опыта и имеющихся данных предлагается следующая модель делимитации урбанизированных ареалов (УА):

1) определяются скопления строений (домов, зданий и сооружений) на расстоянии не более 100 м до ближайшего строения (в упрощенном виде это область сплошной застройки населенных пунктов);

2) величина разрывов в застройке с обеих сторон автомобильной дороги ${ }^{16}$ между скоплениями строений не должна превышать:

- единичный разрыв - не более 2 км$^{17}$ с учетом исключений территорий, которые невозможно застроить ${ }^{18}$ или не более 5 км без исключения таких территорий ${ }^{19}$;

- минимальные суммарные разрывы по одной из не более чем пяти выбранных дорог - не более 5 км $^{20}$ с учетом исключения территорий, которые невозможно застроить, при расчете от скопления строений с

\footnotetext{
16 Дороги с паромными переправами не принимаются в расчет.

${ }^{17}$ Как в Канаде; в США - 0,5 мили, в Австралии - 1,5 км.

18 Мосты и гидротехнические сооружения (дамбы, плотины), дороги, к которым примыкают объекты транспортной инфраструктуры (аэропорты, железнодорожные станции, АЗС, автостоянки), а также кладбища, обустроенные городские парки, стадионы.

${ }^{19}$ В США - 6 миль $(9,7$ км).

${ }^{20}$ В США - 4 мили (6,4 км), в остальном соответствует критериям, принятым в США.
} 
наибольшей численностью населения или от скопления, численность жителей которого превышает 50 тыс.;

3) после этого границы УА корректируются по границам населенных пунктов, более $50 \%$ населения которых проживает в скоплениях, включенных в УА, за исключением частей населенных пунктов, образующих самостоятельные УА численностью более 5 тыс. жителей или единичный разрыв в застройке до которых составляет более 10 км.

Дополнительную сложность расчета урбанизированных ареалов в России создает несоразмерность административно-территориального деления низового уровня: постоянно идущий процесс укрупнения поселений, ликвидация поселений вследствие преобразования муниципальных районов в городские округа, наличие огромных разрывов между частями одного города, доходящих до $100 \mathrm{~km}^{21}$. Даже если выбрать поселения в качестве «строительных блоков» для формирования УА там, где они еще существуют, то максимальные разрывы между границами населенных пунктов, входящих в одно поселение, составляют десятки, а то и сотни километров. Следовательно, в качестве «строительных блоков» для формирования УА необходимо использовать населенные nyнкты . При этом нами, с целью упрощения оценки множества УА при небольшой погрешности, было принято допущение объединения населенных пунктов, наиболее близко расположенных друг к другу, если их общая численность составляет менее 100 человек. А для объективности оценки УА города (или административных районов города) с удаленными микрорайонами приходилось оценивать численность населения этих удаленных микрорайонов, составляющих самостоятельные УА, исходя из произведения пропорции избирателей, живущих в них, в общем количестве избирателей города на население самого города (или административных районов города).

\section{ВЫБОР МОДЕЛИ ДЕЛИМИТАЦИИ МЕТРОПОЛИТЕНСКИХ АРЕАЛОВ}

Чтобы достичь цели статьи по выработке модели делимитации городских агломераций, т.е. метрополитенских ареалов (МА), подходящей для условий России, наиболее достоверным методом видится проведение регрессионного анализа зависимости площади сформированных зарубежных МА по различным показателям от их населения с применением гравитационного критерия. И в дальнейшем, исходя из результатов анализа, построить модель делимитации МА по гравитационному критерию.

Вначале, с помощью гравитационного критерия Рейли-Конверса, по оцененным статистическими ведомствами разных стран агломерациям и агломерационным образованиям исследуем полученные величины степени $v$ и коэффициента $k$ в формуле (6) аппроксимирующей функции (рисунок 1, верхний график). Кроме этого, можно провести наглядное сравнение полученных по аппроксимирующей функции размеров средних расчетных радиусов (радиусов) для агломерации численностью 1 млн и 50 тыс. жителей

\footnotetext{
${ }^{21}$ Микрорайон Вынгапуровский города Ноябрьск отстоит от основной части города на 100 км при отсутствии какой-либо застройки между ними.
} 
(рисунок 1, нижний график). Исходные данные и ссылки на источники приведены в таблице П1 Приложения.

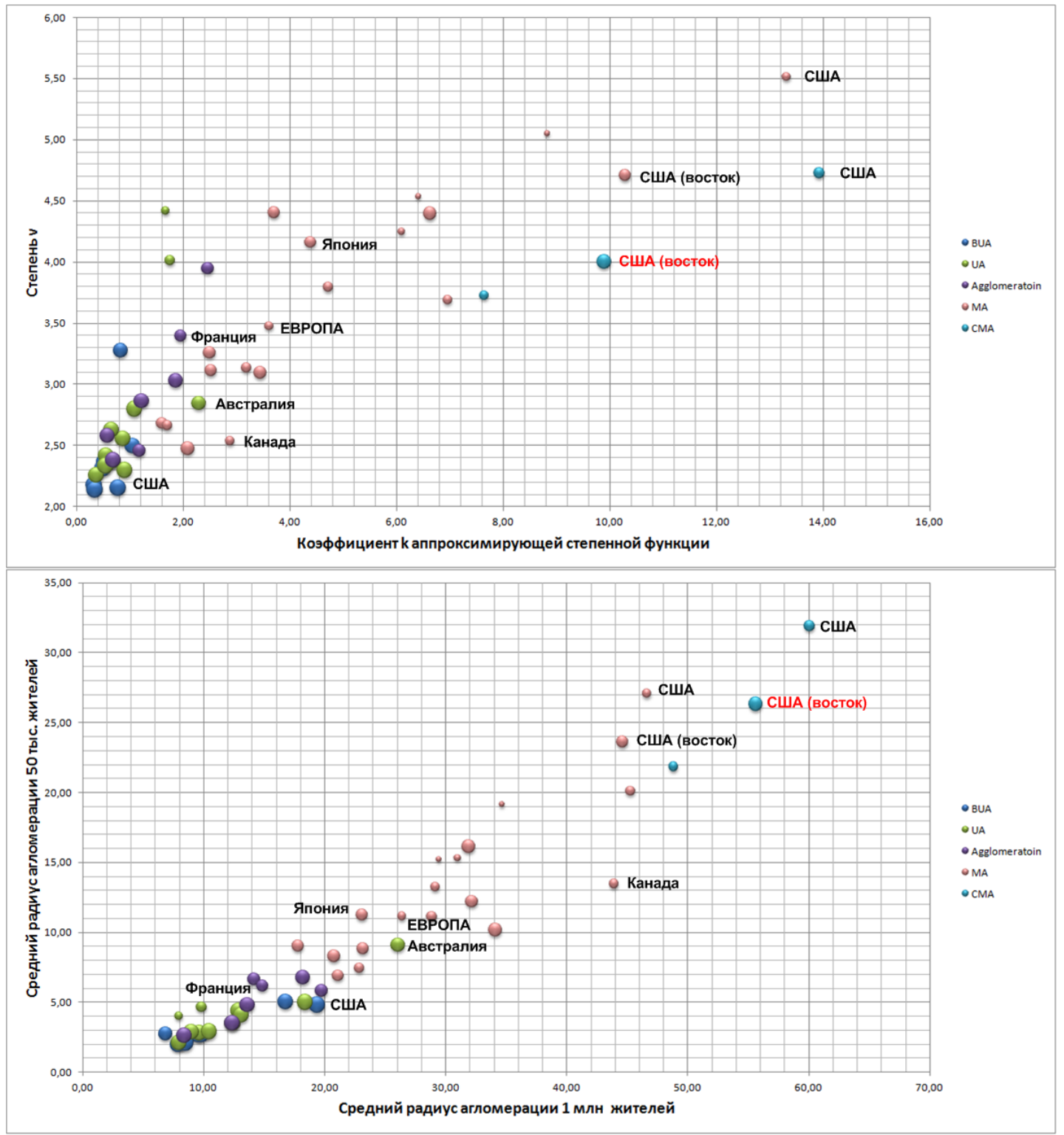

\section{Рисунок 1. Характеристики аппроксимирующих функций для агломерационных образований разных стран}

Источник: Расчеты автора (таблииа П-1 Приложения).

Примечания: Размеры пунсонов определяются величиной коэффициента детерминации аппроксимирующей функиии $R^{2}$; красным шрифтом отмечено наблюдение, принятое автором за основу формирования метрополитенских агломераций.

Автором были проведены исследования для различных известных видов агломераций, применяемых зарубежными странами, классифицированных по пяти основным видам: 1) BUA (Built-up areas) - дословно: застроенные территории, это УА, определенные по критерию минимально допустимой плотности населения, включают только полностью застроенные территории; 2) собственно урбанизированные ареалы - UA (Urban areas), определенные по критерию минимально допустимых разрывов, включают также незастроенные территории внутри территорий застройки; 3 ) «агломерации» - такое 
определение к ним применяется в своих странах (Agglomeration), как правило, они ничем не отличаются от UA; 4) метрополитенские ареалы (MA, Metropolitan areas) - учет агломерационных образований ведется под этим названием, хотя не везде они ему соответствуют, наряду с СМА определяются по административным границам; 5) СМА (Combined metropolitan areas) - объединенные метрополитенские ареалы США.

Из рисунка 1 следует, что многие урбанизированные ареалы (BUA, UA и собственно, «агломерации») характеризуются почти одинаковой плотностью территории: показатель степени $v$ близок к 2 , но не меньше. Это объяснимо, так как чем населённее УА, тем больше плотность застройки городского центра и его территория. К примеру, различается «одноэтажная Америка» (BUA CША) - огромные городские территории одинаковой плотности населения (1-, 2-этажной застройки), но с наличием у крупных городов плотно застроенных кварталов (даунтауны) - показатель степени немного выше 2, а огромные по площади территории характеризуются большим значением k, чем у европейских BUA.

Показатель степени метрополитенских ареалов (MA, CMA) заметно выше уровня одинаковой плотности ( $\mathrm{v}=2)$ и, за исключением нескольких серий наблюдений, находится в диапазоне от 3 до 5. Это объясняется включением в МА больших по площади незастроенных территорий из-за перехода на административные границы и большей плотностью населения у более населенных агломераций.

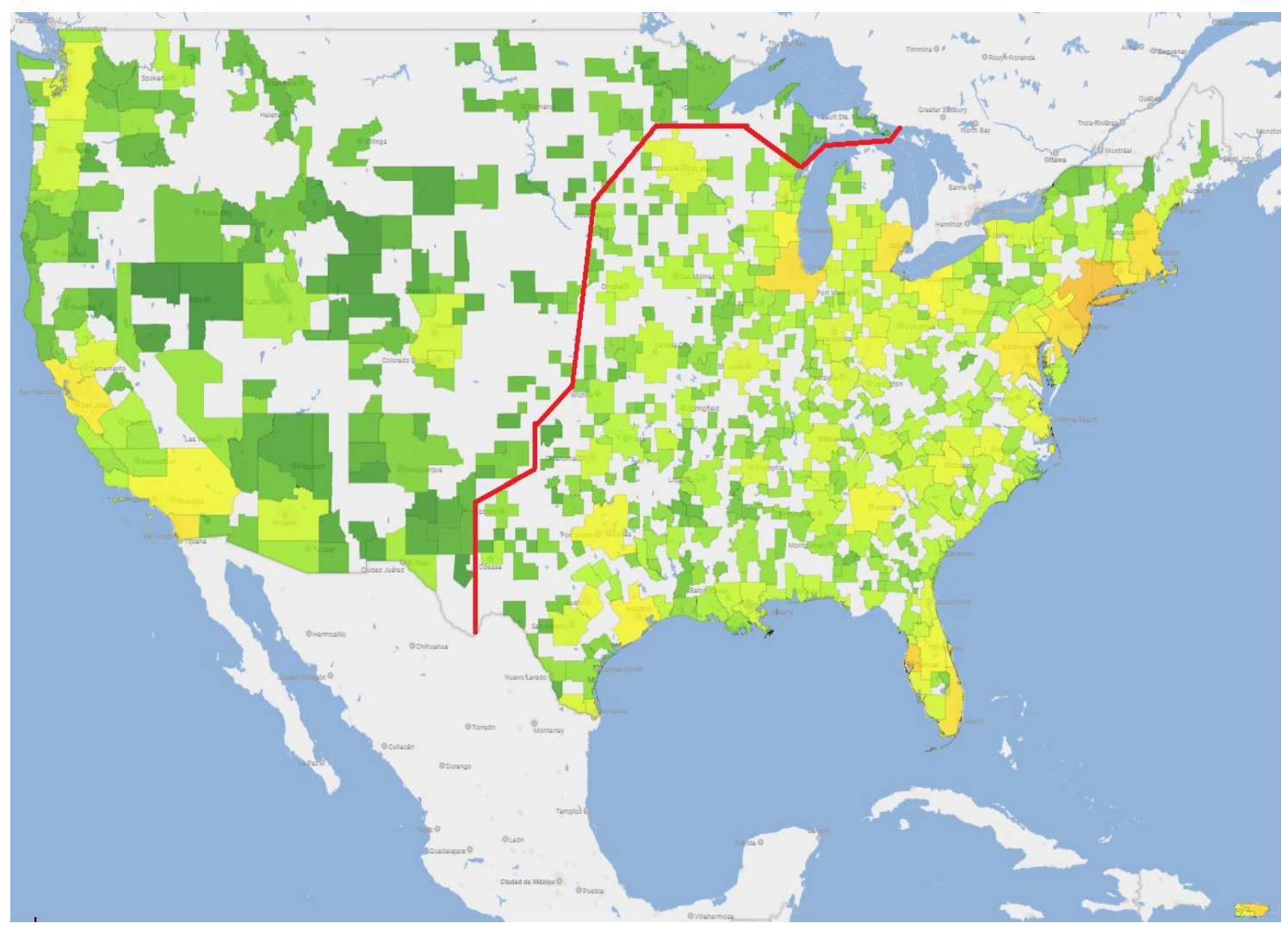

Рисунок 2. Метрополитенские ареалы США

Источник: City population. USA: Combined Metropolitan Areas. URL: http://citypopulation.de/en/usa/combmetro/

Примечание: К востоку от красной линии показана выборка CSA, MSA для дальнейшего анализа. 
На наш взгляд, для определения зависимости площади от населения лучше всего подходят метрополитенские статистические ареаль (Metropolitan statistical area, MSA) ${ }^{22}$ и комбинированные статистические ареальл (Combined statistical area, CSA) ${ }^{23}$, рассчитываемые в США - они характеризуются средним среди наблюдаемых стран предельным уровнем маятниковой трудовой миграции - 25\%, а также учитывают полицентричность агломераций. Автором были проведены исследования зависимости площади американских агломераций от их населения в четырех случаях: 1) моноцентрические MSA в целом по США с Пуэрто-Рико; 2) моноцентрические MSA к востоку от красной линии ${ }^{24}$ на рисунке 2 ; 3) полицентрические CSA в целом по США с Пуэрто-Рико; 4) полицентрические CSA к востоку от красной линии на рисунке 2.

B результате коэффициент детерминации R-квадрат, показывающий устойчивость взаимосвязи показателей, принимает максимальное значение $72 \%$ для полицентрических CSA восточной части США. Это можно объяснить тем, что MSA США, также как и функииональные урбанизированнье ареальл (FUA) Евросоюза, - это территория, «обрамленная с краёв» другими агломерациями, которые построены на базе близко расположенных друг к другу УА численностью более 50 тыс. жителей ${ }^{25}$. Исходя из этого получается, что на карте полицентрические CSA восточной части CША, присоединившие обратно эти «обрамленные» территории, выглядят вполне округло (рисунок 2).

Зависимость среднего предельного радиуса CSA восточной части США от проживающего в них населения дает показатель степени $v=4,00$, т. е. показывает степенную зависимость квадратичного корня площади от населения, а коэффициент $k$ равен 9,89, округлённо $k=10$ (таблица П-1 Приложения). Эту зависимость предлагаем взять за основу формируемой модели делимитации метрополитенских ареалов.

Хотя есть ряд факторов, говорящих о необходимости как увеличения, так и уменьшения коэффициента $k$, оставим его значение без изменения. Факторами, увеличивающими коэффициент $k$, являются: 1) необходимость учета населения УА, а не МА в формуле модели; 2) оценка предельного расстояния МА не по прямой линии, а по автодорогам. Факторами, уменьшающими коэффициент $k$, являются: 1) расширение территорий МА сверх расчетного предельного расстояния за счет включения территорий, находящихся в зоне тяготения другого УА, уже включенного в данный МА; 2) завышенные границы американских CSA, на основе которых предложена модель делимитации МА, по сравнению с аналогичными по населению МА других стран.

Сравним полученные результаты с результатами делимитации городских агломераций России согласно Обосновывающим материалам к Стратегии пространственного развития России на период до 2025 г. (далее - СПР; Минэкономразвития 2018), а также с полученными Е.В. Антоновым и А.Г. Махровой (2019) (таблица П-1 Приложения). Заметим, что агломерации, рассчитанные по СПР, очень близки к

\footnotetext{
22 Соответствует термину «метрополитенский ареал» (МА), принятому в статье.

${ }^{23}$ Соответствует термину «комбинированный метрополитенский ареал» (КМА), принятому в статье.

${ }^{24}$ Как видно из рисунка 2, к востоку от красной линии более мелкая нарезка на графства, по которым устанавливаются границы MSA и CSA.

${ }^{25}$ Наглядно было показано на примере агломерации Рейн-Рур (Райсих 2020).
} 
агломерациям, рассчитанным по базовому варианту. Наибольшие коэффициенты детерминации показали агломерации, рассчитанные по СПР (53\%), базовому ${ }^{26}(52 \%)$ и расширенному $^{27}$ (47\%) варианту согласно (Антонов, Махрова 2019). Зависимость среднего предельного радиуса агломераций от их населения, рассчитанная по данным методикам, характеризуется степенной функцией корня третьей-четвертой степени. При этом средний предельный радиус по аппроксимирующей степенной функции CSA восточной части США оказывается между значениями по СПР и базовому варианту с одной стороны, и расширенному варианту с другой стороны, для агломераций численностью 50 тыс. и 1 млн жителей, а для такой агломерации, как Московская $(20 \text { млн жителей })^{28}-$ значительно меньше значений радиусов по всем этим вариантам. Что касается МА других стран, то рассчитанные на их основе средние предельные радиусы оказываются существенно меньше и американских CSA и MSA, и всех указанных выше вариантов расчета российских агломераций.

Следовательно, распространенный среди российских специалистов критерий 1,5часовой и, тем более, 2-часовой транспортной доступности для делимитации границ агломерации немного завышает границы даже по сравнению с полицентрическими метрополитенскими ареалами США.

На основании выполненных расчетов сформулируем модель делимитащии метрополитенских ареалов (МА).

В метрополитенские ареалы (МА) включаются статистические единицы районного уровня (муниципальные образования, поселения, сельские округа), центры которых расположены от центра города, образовывающего урбанизированный ареал (УА), на расстоянии по автомобильным дорогам не более:

$$
\mathrm{L}_{\mathrm{j}}=\sqrt[4]{10 * \mathrm{P}_{\mathrm{j}}} \text { или } \mathrm{L}_{\mathrm{j}}=10 * \sqrt[4]{\mathrm{N}_{\mathrm{j}}}
$$

где $\mathrm{L}_{\mathrm{j}}$ - предельное расстояние, км; $\mathrm{P}_{\mathrm{j}}, \mathrm{N}_{\mathrm{j}}=\mathrm{P}_{\mathrm{j}} / 1000$ - население УА, образующего МА, человек и тыс. человек соответственно.

Один МА в полном составе включается в состав другого МА, если расстояние между центрами этих МА не больше предельного. Если какая-либо статистическая единица районного уровня попадает по формуле (7) одновременно в два или более МА, то она включается в состав того МА, относительное расстояние ${ }^{29}$ до центра которого меньше.

Проведенное исследование показало, что использование гравитационного критерия для делимитации городских агломераций дает очень хорошее приближение к результатам делимитации МА статистическими ведомствами зарубежных государств, основанным на применении критерия интенсивности маятниковой трудовой миграции (МТМ).

\footnotetext{
${ }^{26}$ Включая муниципальные образования, полностью расположенные в пределах 2-часовой транспортной доступности.

${ }^{27}$ Включая муниципальные образования, хотя бы частично расположенные в пределах 2-часовой транспортной доступности.

28 Оценка Московской агломерации по базовому, расширенному вариантам и по СПР дает численность населения 21 млн жителей, оценка по модели МА, выработанной в данной статье - 20 млн.

${ }^{29}$ Отношение расстояния от центра статистической единицы до центра МА к предельному расстоянию МА.
} 
Его использование применимо к делимитации российских агломераций как в качестве замещающей модели при отсутствии данных о величинах МТM, так и в качестве модели, показывающей потенциальные возможности взаимодействия городов и территорий.

Используя гравитационный критерий делимитации городских агломераций, сформулируем также модель делимитации полицентрических МА. Полицентрическим МА (аналогом американских CSA - объединенных статистических ареалов) может быть объединенный (комбинированный) метрополитенский ареал (ОМА или КМА). К некоторым из таких агломерационных объединений, характеризующихся выраженной полицентричностью, может быть применен термин конурбация - городская агломерация полицентрического типа, имеющая в качестве ядер несколько более или менее одинаковых по размеру и значимости городов или городских территорий. Используем два ограничения: 1) условием объединения МА в ОМА должно стать наличие статистических единиц районного уровня (муниципальные образования, поселения, сельские округа), которые можно включить по нашей модели делимитации МА в оба МА; 2) численность населения присоединяемых МА должна быть выше порогового уровня ${ }^{30}$.

Соответственно предлагаем следующую модель делимитации объединенных метрополитенских ареалов (ОМА).

Несколько метрополитенских ареалов численностью населения свыше 10 тыс. человек ${ }^{31}$ в каждом могут создать объединенный метрополитенский ареал (OMA), если имеются населенные пункты, которые по нашей модели делимитации МА можно включить одновременно в два и более из этих МА. При этом связь между любыми двумя МА, включенными в ОМА, может проходить не более чем через два МА.

Последнее ограничение справедливо для избегания формирования длинных цепочек MА, включаемых в ОМА, а с другой стороны, позволяет классифицировать в ОМА все общепринятые российские полицентрические агломерации ${ }^{32}$. Для России это, прежде всего, справедливо для Северного Кавказа, где, не будь этого ограничения, мог бы быть сформирован ОМА от Пятигорска до Дербента.

Объединенные метрополитенские ареалы могут являться базисом для формирования экономических микрорайонов России (Лейзерович 2010), но это тема другого исследования.

\footnotetext{
30 Подобное ограничение есть в США, где не рассчитываются микрополитенские ареалы численностью менее 10 тыс. человек.

${ }^{31}$ Исходим из порогового уровня микрополитенского статистического ареала США.

${ }^{32}$ Например, агломерации Самара - Тольятти, Ростов-на-Дону - Таганрог - Шахты, выделяемые в работах (Полян 2014; Минэкономразвития 2018; Антонов, Махрова 2019) и многих других.
} 


\section{АПРОБАЦИЯ РАЗРАБОТАННЫХ МОДЕЛЕЙ ДЕЛИМИТАЦИИ УРБАНИЗИРОВАННЫХ АРЕАЛОВ, МЕТРОПОЛИТЕНСКИХ АРЕАЛОВ И ОБЪЕДИНЕННЫХ МЕТРОПОЛИТЕНСКИХ АРЕАЛОВ НА ПРИМЕРЕ РОССИЙСКИХ АГЛОМЕРАЦИЙ}

На основе определенных моделей делимитации УА, $М A$ и OMA автором была проведена оценка состава и границ большого числа российских агломераций.

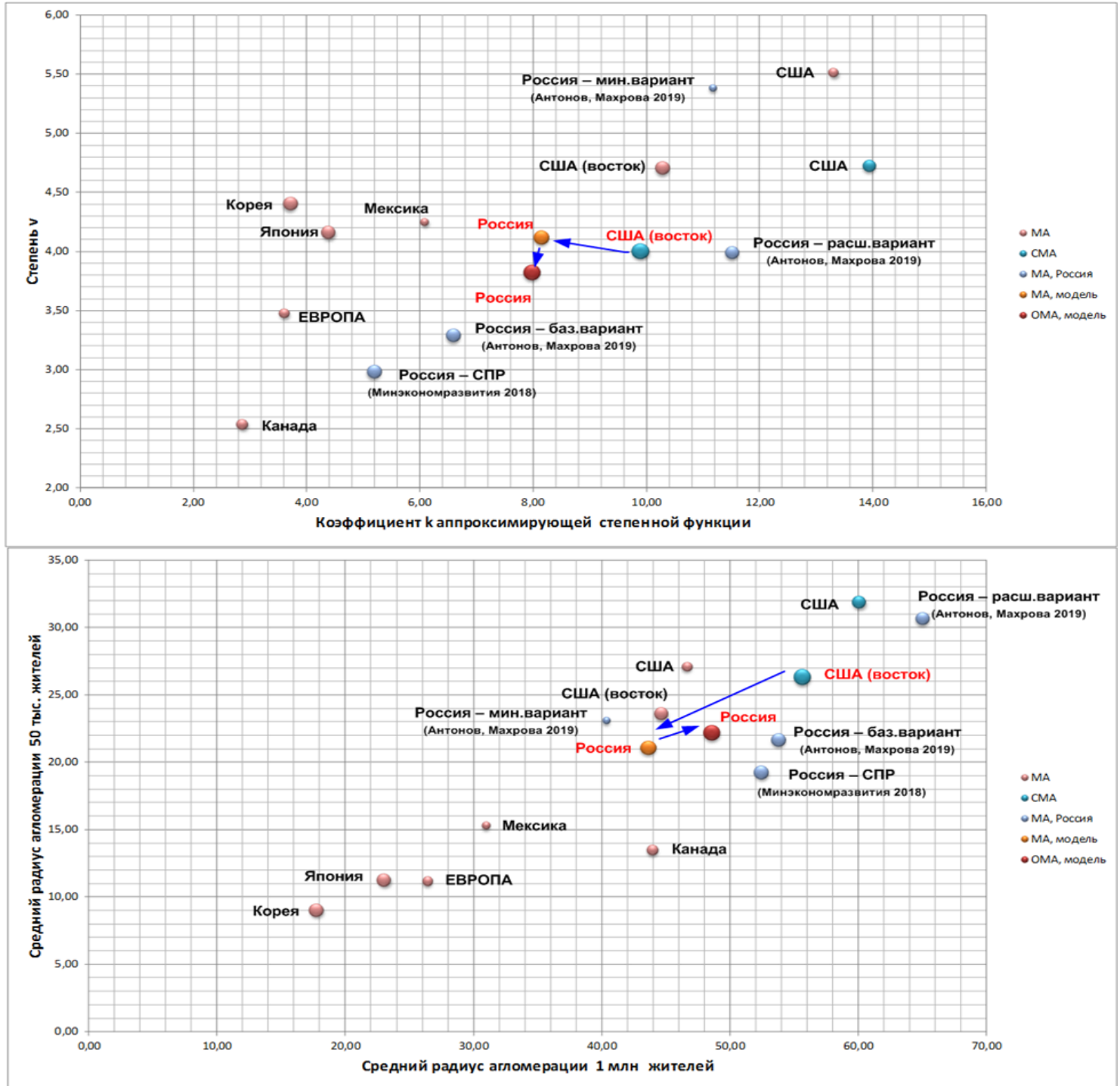

Рисунок 3. Сравнение характеристик выбранной модели делимитации метрополитенских ареалов и аппроксимирующих функций для метрополитенских ареалов разных стран

Источники: Расчеты автора (таблица П-1 Приложения); данные о площади муниципальных образований России: Госкомстат РФ, База данных показателей муниципальных образований России, URL: https://www.gks.ru/dbscripts/munst/munst33/DBInet.cgi\#1.

Примечания: Размеры пунсонов определяются величиной коэффициента детерминации аппроксимирующей функции $R^{2}$; красным шрифтом отмечены: наблюдение, принятое автором за основу формирования метрополитенских агломераций, результаты оценки по выбранной модели российских агломераций; синими стрелками показано движение модели от выбранного образиа до фактических результатов оченки. 
На дату переписи 2010 г. в России насчитывалось 2490 урбанизированных ареалов численностью не менее 5 тыс. человек, 1137 метрополитенских ареалов численностью не менее 10 тыс. человек ${ }^{33}, 848$ объединенных метрополитенских ареалов, включая одиночные метрополитенские ареалы. Оценка осуществлялась по границам муниципальных образований низового (3-го) уровня России - городским и сельским поселениям в составе муниципальных районов, а также по частям городских или муниципальных округов, включая сельсоветы, и по отдельным населенным пунктам ${ }^{34}$.

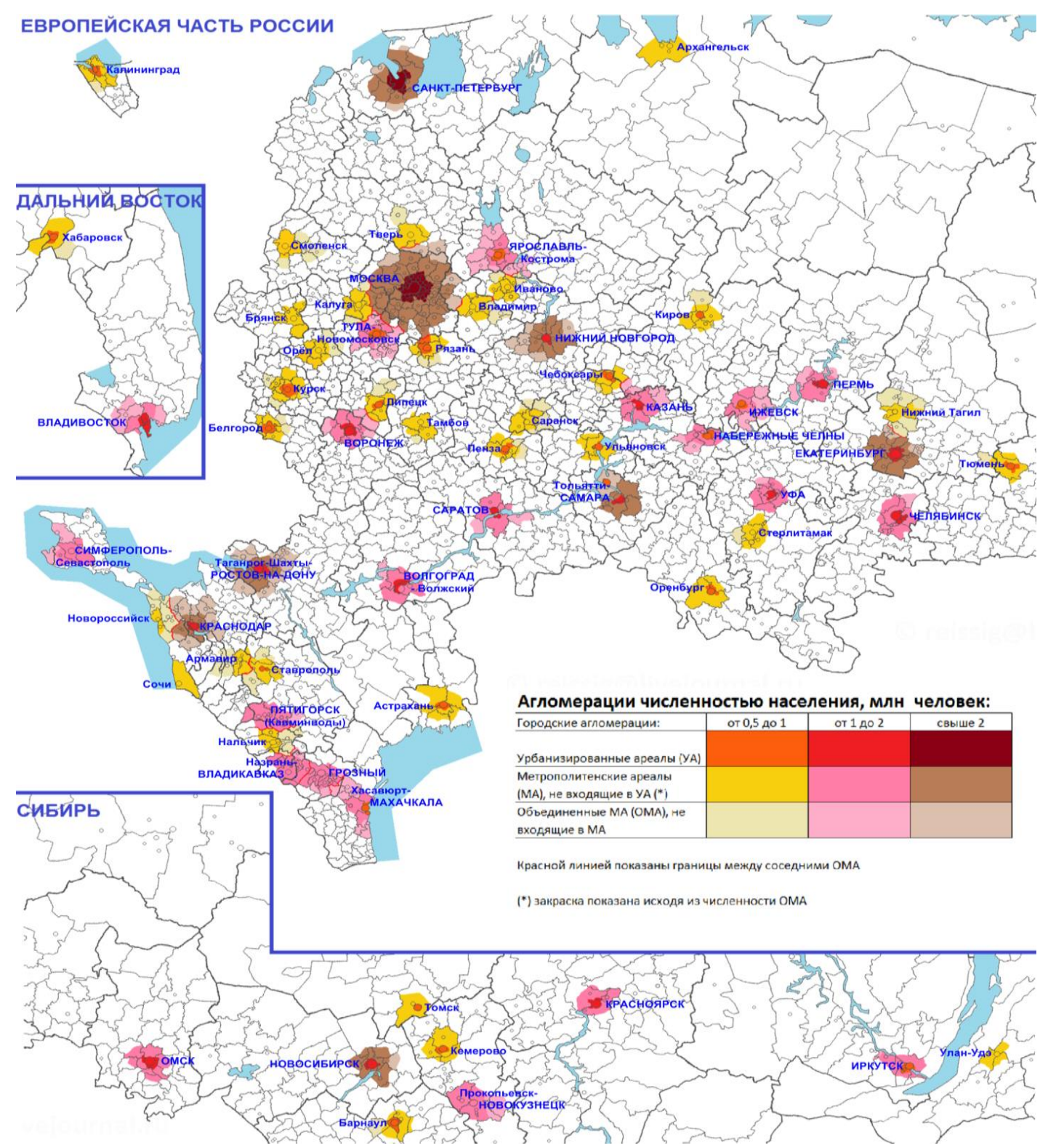

Рисунок 4. Границы крупнейших городских агломераций России

Результаты оценки российских МА и ОМА (рисунок 3 и таблица П-1 Приложения) показывают, что коэффициент $k$ аппроксимирующей степенной функции оказывается равен

33 По аналогии с принятой в США классификацией из них собственно метрополитенские ареалы численностью свыше 50 тыс. человек - 323, микрополитенские ареалы численностью от 10 до 50 тыс. человек -814 .

${ }^{34}$ Некоторые урбанизированные ареалы также разделялись по частям населенных пунктов (городов). 
8 вместо 10 (занижен на 20\%) при неизменном показателе степени ( $v=4)$. Однако такое полученное занижение вполне приемлемо, так как по своим размерам метрополитенские ареалы России получаются расположенными между МА других стран и американскими МА (MSA и CSA).

В итоге в России были выделены следующие крупные агломерации численностью свыше 500 тыс. человек по состоянию на 1 января 2020 г.:

1) урбанизированные ареалы: 17 численностью свыше 1 млн человек и 25 численностью от 0,5 до 1 млн человек (таблица П-2 Приложения);

2) метрополитенские ареалы: 21 численностью свыше 1 млн человек и 38 численностью от 0,5 до 1 млн человек (таблица П-3 Приложения);

3) объединенные метрополитенские ареалы: 29 численностью свыше 1 млн человек и 34 численностью от 0,5 до 1 млн человек (таблица П-4 Приложения).

Наглядная визуализация получившихся границ российских агломераций (УА, МА и OMА) приведена на рисунке 4.

\section{ОБСУЖДЕНИЕ РЕЗУЛЬТАТОВ}

Применение моделей делимитации УА, МА и ОМА открывает широкие возможности для различных экономико-географических, демографических исследований структуры расселения населения и тенденций урбанизации. В таблицах П-2, П-3, П-4 Приложения показан рост крупных агломераций России и их составляющих в течение второго десятилетия XXI века - с момента переписи 2010 г. по 1 января 2020 г. Видно, что население России ускоренными темпами стягивается крупными агломерациями и их рост в 5-8 раз превышает рост населения страны: население 42 крупных УА выросло на 8,9\%, 59 крупных МА - на 7,1\%, 63 крупных ОМА - на 6,1\%, в то время как население России за этот период выросло только на $1,1 \%{ }^{35}$. Доля в населении России крупных УА, МА и ОМА за эти годы выросла на 2,8-3,2\% и составляет теперь 39,0; 56,0 и 63,4\% соответственно.

Более чем на 10\% за данный период выросло население таких крупных УА, как Москва, Санкт-Петербург, Новосибирск, Екатеринбург, Казань, Красноярск, Краснодар, Тюмень, Иркутск, Томск, Ставрополь, Калининград, Белгород. В то же время падение населения зафиксировано в УА Волгограда, Тольятти и Тулы. Среди МА и ОМА агломераций с отрицательной динамикой больше: 11 из 59 МА и 15 из 63 ОМА.

Можно также выделить зоны наибольшего и наименьшего роста в «слоёном пироге» агломераций за этот период. Наибольший рост в $23 \%$ отмечен в так называемой субурбии зоне сплошной застройки, непосредственно примыкающей к границам главного города агломерации, т. е. это УА за исключением главного города. Понятно, что такой рост субурбии может быть обеспечен только за счет превалирующего миграционного прироста, объясняемого более привлекательными, чем в главном городе, ценами на жильё при сравнимой или незначительно уступающей транспортной доступности. Рекорд роста

\footnotetext{
${ }^{35}$ Без учета Крыма и Севастополя.
} 
субурбии среди УА свыше 1 млн жителей в 119\% принадлежит Санкт-Петербургу, именно там за прошедшее десятилетие возникло 2 полноценных города «с нуля»: Мурино и Кудрово.

С другой стороны, рост населения периферии $M A$ (т. е. МА за исключением УА главного города) с переписи 2010 г. по 1 января 2020 г. в 2,7\% близок к среднему росту населения России (1,1\%), а население прочих $M A$, входящих в состав OMA, вообще снизилось на 0,8\%. Периферия МА не столь притягательна для внешней миграции сказывается большая транспортная удалённость по сравнению с сурурбией, в то время как её население не убывает, так как вовлечено в ежедневную маятниковую трудовую миграцию (МТМ) с главным городом или с УА агломерации. А вот прочие МА, как правило, характеризуются сложившимися промышленными центрами с депрессивным социально-экономическим положением и существенно меньшей вовлечённостью в МТМ в главный город ОМА. Соответственно, их население, как правило, убывает (примеры: Тольятти, Шахты, Асбест, Павлово).

Интересно провести сравнение ОМА по коэффициенту развитости агломераций согласно методике Института географии АН СССР по формуле (1), только вместо городов и пгт использовать урбанизированные ареалы численностью свыше 20 тыс. и от 5 до 20 тыс. человек соответственно. А людность городской агломерации оценивать как сумму УА, численностью свыше 250 тыс. человек каждый, входящих в этот МА:

$$
K_{\text {разв }}=P_{u} *\left(M_{u} * m_{u}+N_{u} * n_{u}\right),
$$

где $P_{u}$ - суммарная численность населения УА свыше 250 тыс. чел., входящих в данных МА, млн чел.; $M_{u}$ и $N_{u}$ - количество УА численностью свыше 20 тыс. чел. и от 5 до 20 тыс. чел., входящих в данный МА, соответственно; $m_{u}$ и $n_{u}-$ доли в суммарной численности населения агломерации УА численностью свыше 20 тыс. чел. и от 5 до 20 тыс. чел., входящих в данный МА, соответственно.

Данный подход одновременно с использованием для делимитации МА гравитационного критерия, на наш взгляд, позволяет обойти большинство недостатков и допущений различных методик оценки развитости агломераций.

Расчет коэффициентов развитости по формуле (8) на 2010 и 2020 г. для крупных российских агломераций приведён в таблице. Согласно классификации П.М. Поляна (2014: 355), одного из основоположников данной методики, получается наличие в России:

1) 2 крупнейших ОМА (Москва - Электросталь, Санкт-Петербург) с коэффициентом развитости более 50 ;

2) 5 сильно развитых ОМА (Ростов-на-Дону - Таганрог - Шахты, Самара - Тольятти, Екатеринбург, Нижний Новгород, Краснодар) с коэффициентом развитости от 10 до 50 (в 2010 г. также 5);

3) 5 pазвитых ОМА с коэффициентом развитости от 5 до 10 (в 2010 г. также 5) при этом произошла замена полицентрических агломераций Ярославль - Кострома Рыбинск и Тула - Новомосковск агломерациями Казани и Уфы;

4) 17 слабо развитых ОМА с коэффициентом развитости от 2,5 до 5 (в 2010 г. - 14); 
5) 23 наименее развитых ОМА с коэффициентом развитости от 1 до 2,5 (в 2010 г. также 23), причём, в соответствии с методикой в 2010 г. Тюмень, Саранск и Сочи не проходили тест на развитость;

6) 11 потенциальных ОМА (Чебоксары, Ульяновск, Хабаровск, Астрахань, Оренбург, Рязань, Стерлитамак, Тверь, Улан-Удэ, Орёл и Тамбов) с коэффициентом развитости менее 1 (в 2010 г. - 14).

Таблица 1. Коэффициенты развитости крупных ОМА

\begin{tabular}{|c|c|c|c|c|c|c|}
\hline \multirow{3}{*}{ OMA $^{36}$} & \multicolumn{4}{|c|}{ Количество УА } & \multirow{2}{*}{\multicolumn{2}{|c|}{$\begin{array}{c}\text { Коэффициент } \\
\text { развитости }\end{array}$}} \\
\hline & \multicolumn{2}{|c|}{ > 20 тыс. чел. } & \multicolumn{2}{|c|}{ 5-20 тыс. чел. } & & \\
\hline & 2010 г. & 2020 г. & 2010 г. & 2020 г. & 2010 г. & 2020 г. \\
\hline Москва - Электросталь * & 45 & 47 & 50 & 49 & 666,3 & 774,6 \\
\hline Санкт-Петербург * & 11 & 11 & 18 & 17 & 54,9 & 62,1 \\
\hline $\begin{array}{l}\text { Ростов-на-Дону - Таганрог - } \\
\text { Шахты * }\end{array}$ & 14 & 13 & 15 & 14 & 22,7 & 21,6 \\
\hline Самара - Тольятти * & 7 & 7 & 11 & 11 & 13,6 & 13,6 \\
\hline Екатеринбург * & 8 & 8 & 7 & 9 & 11,7 & 13,2 \\
\hline Нижний Новгород * & 9 & 9 & 15 & 14 & 12,3 & 12,3 \\
\hline Краснодар * & 15 & 15 & 31 & 30 & 13,7 & 16,7 \\
\hline Новосибирск * & 5 & 5 & 11 & 11 & 8,0 & 9,0 \\
\hline Махачкала * & 8 & 8 & 29 & 30 & 8,5 & 9,5 \\
\hline Казань * & 4 & 4 & 6 & 7 & 4,5 & 5,1 \\
\hline Челябинск * & 3 & 3 & 8 & 8 & 4,0 & 4,3 \\
\hline Волгоград - Волжский * & 4 & 4 & 4 & 4 & 4,0 & 3,9 \\
\hline Уфа * & 5 & 6 & 7 & 9 & 4,8 & 6,2 \\
\hline Воронеж * & 3 & 3 & 9 & 9 & 3,4 & 3,7 \\
\hline Ярославль - Кострома * & 6 & 5 & 4 & 5 & 5,0 & 4,3 \\
\hline Симферополь - Севастополь & 7 & 7 & 10 & 9 & 5,0 & 5,4 \\
\hline Красноярск * & 3 & 3 & 2 & 3 & 3,0 & 3,4 \\
\hline Омск * & 1 & 1 & 10 & 10 & 1,8 & 1,8 \\
\hline Пермь * & 4 & 3 & 10 & 11 & 4,4 & 3,9 \\
\hline Саратов * & 3 & 4 & 2 & 1 & 3,1 & 4,2 \\
\hline Тула - Новомосковск * & 6 & 6 & 13 & 13 & 5,5 & 3,8 \\
\hline Грозный & 11 & 11 & 18 & 22 & 3,4 & 4,1 \\
\hline Иркутск * & 3 & 4 & 8 & 7 & 2,2 & 3,0 \\
\hline Ижевск * & 5 & 5 & 4 & 4 & 3,0 & 3,1 \\
\hline Пятигорск * & 10 & 10 & 15 & 14 & 2,5 & 2,5 \\
\hline Новокузнецк - Прокопьевск * & 7 & 7 & 4 & 5 & 3,1 & 3,1 \\
\hline Владивосток * & 4 & 4 & 8 & 8 & 2,9 & 3,0 \\
\hline Владикавказ - Назрань & 7 & 8 & 9 & 8 & 2,7 & 2,9 \\
\hline Набережные Челны * & 5 & 5 & 3 & 3 & 2,4 & 2,5 \\
\hline Новороссийск & 7 & 7 & 14 & 18 & 1,9 & 2,5 \\
\hline Тюмень * & 1 & 1 & 6 & 8 & 0,8 & 1,3 \\
\hline Ставрополь * & 5 & 4 & 8 & 8 & 2,4 & 2,3 \\
\hline Барнаул * & 2 & 2 & 4 & 5 & 1,3 & 1,4 \\
\hline Нальчик & 7 & 7 & 13 & 14 & 2,1 & 2,1 \\
\hline Калининград & 4 & 4 & 8 & 8 & 1,9 & 2,2 \\
\hline Чебоксары * & 1 & 1 & 5 & 5 & 0,7 & 0,8 \\
\hline Ульяновск * & 1 & 1 & 5 & 5 & 0,7 & 0,7 \\
\hline Томск * & 2 & 2 & 5 & 4 & 1,1 & 1,2 \\
\hline Пенза & 2 & 2 & 6 & 6 & 1,1 & 1,2 \\
\hline Липецк & 4 & 3 & 4 & 5 & 1,9 & 1,5 \\
\hline Хабаровск * & 1 & 1 & 7 & 6 & 0,9 & 0,9 \\
\hline Астрахань * & 1 & 1 & 6 & 6 & 0,8 & 0,8 \\
\hline Киров & 3 & 3 & 6 & 6 & 1,5 & 1,7 \\
\hline
\end{tabular}

${ }^{36}$ указаны УА свыше 250 тыс. чел.

WWW.DEMREVIEW.HSE.RU 


\begin{tabular}{|c|c|c|c|c|c|c|}
\hline \multirow{3}{*}{$\mathrm{OMA}^{36}$} & \multicolumn{4}{|c|}{ Количество УА } & \multirow{2}{*}{\multicolumn{2}{|c|}{$\begin{array}{c}\text { Коэффициент } \\
\text { развитости }\end{array}$}} \\
\hline & \multicolumn{2}{|c|}{$>20$ тыс. чел. } & \multicolumn{2}{|c|}{ 5-20 тыс. чел. } & & \\
\hline & 2010 г. & 2020 г. & 2010 г. & 2020 г. & 2010 г. & 2020 г. \\
\hline Белгород & 3 & 3 & 6 & 6 & 1,3 & 1,5 \\
\hline Курск & 4 & 2 & 4 & 6 & 1,6 & 1,1 \\
\hline Оренбург * & 1 & 1 & 4 & 4 & 0,6 & 0,7 \\
\hline Иваново & 5 & 4 & 4 & 5 & 2,2 & 1,8 \\
\hline Владимир & 3 & 3 & 7 & 7 & 1,1 & 1,1 \\
\hline Кемерово * & 3 & 3 & 3 & 3 & 1,5 & 1,5 \\
\hline Рязань & 1 & 1 & 4 & 4 & 0,6 & 0,6 \\
\hline Брянск & 3 & 3 & 10 & 8 & 1,7 & 1,5 \\
\hline Армавир & 5 & 5 & 11 & 11 & 1,3 & 1,3 \\
\hline Архангельск & 3 & 3 & 2 & 2 & 1,0 & 1,0 \\
\hline Стерлитамак & 3 & 3 & 2 & 2 & 0,7 & 0,8 \\
\hline Нижний Тагил & 6 & 5 & 6 & 7 & 2,1 & 1,8 \\
\hline Тверь & 2 & 2 & 1 & 1 & 0,7 & 0,8 \\
\hline Саранск & 3 & 3 & 6 & 5 & 0,9 & 1,0 \\
\hline Смоленск & 3 & 3 & 6 & 5 & 1,0 & 1,0 \\
\hline Улан-Удэ & 1 & 1 & 2 & 2 & 0,4 & 0,5 \\
\hline Сочи & 3 & 4 & 3 & 2 & 0,0 & 1,1 \\
\hline Орёл & 2 & 2 & 5 & 5 & 0,8 & 0,7 \\
\hline Тамбов & 3 & 3 & 4 & 4 & 0,9 & 0,9 \\
\hline Калуга & 2 & 2 & 10 & 9 & 1,1 & 1,0 \\
\hline
\end{tabular}

Источник: Расчеты автора на основе (Росстат 2010, 2020), для ОМА Симферополя - Севастополя в т.ч. на основе (Укрстат 2011).

* Агломерации, анализ которых проведён в работе (Антонов, Махрова 2019)

Сравним полученные результаты с оценкой развитости агломераций на 2018 г. (Антонов, Махрова 2019), осуществленной по формуле (1) с использованием городов и посёлков городского типа. Е.В. Антонов и А.Г. Махрова оценили развитость 36 агломераций, все они представлены и в Таблице 1. Состав агломераций различной степени развитости у Е.В. Антонова и А.Г. Махровой немного иной: из 36 агломераций по формуле (1) оказались неразвитыми 2 (Хабаровск и Оренбург), а по формуле (8) - 5 (дополнительно Чебоксары, Ульяновск, Астрахань). Для крупнейших агломераций (Москва, Санкт-Петербург, Самара - Тольятти, Екатеринбург, Нижний Новгород), а также для агломерации Тула - Новомосковск коэффициент развитости при расчете через УА занижается, что объясняется вхождением множества городов и пгт, учитываемых по формуле (1), в состав УА численностью свыше 250 тыс. человек. С другой стороны, обращает внимание традиционное занижение по формуле (1) развитости агломераций юга России, таких как Ростовская, Краснодарская, Махачкалинская. Здесь оказывают влияние два фактора: 1) недоучёт в формуле крупных сельских поселений (станиц и сёл); 2) заниженные границы агломераций даже в самых максимальных вариантах расчёта ${ }^{37}$.

37 Так, на примере Краснодарской агломерации, коэффициент развитости которой по формуле (1) Е.В. Антонов и А.Г. Махрова оценили в пределах $1,1-3,5$, в то время как коэффициент развитости ОМА Краснодар по формуле (8) получился минимум в 4-5 раз больше. Определяющую роль сыграл недоучёт в формуле (1) следующих факторов: 1) 5 крупных (свыше 20 тыс. чел.) и 28 средних (от 5 до 20 тыс. чел.) станиц и сёл, образующих самостоятельные УА; 2) невключение в агломерацию территорий Славянского, Калининского, Тимашевского, Кореновского, Усть-Лабинского районов, расстояние до центров которых находится в пределах 1-1,25-часовой доступности, что соответствует принятым авторами критериям агломерации. 


\section{ЗАКЛЮЧЕНИЕ}

В результате проведенного анализа и систематизации международного и отечественного опыта делимитации городских агломераций была показана необходимость двухэтапного подхода к их делимитации. На первом этапе с использованием морфологического подхода, т. е. определения границ слитной застройки, должно быть определено ядро агломерации (или урбанизированный ареал, УА), а на втором этапе, исходя из характеристик взаимодействия периферии агломерации с ее ядром с применением функционального подхода, - уже границы самой городской агломерации (или метрополитенского ареала, MA).

Среди применяемых критериев для определения границ и состава ядра агломерации наиболее простым и точным методом является применение опыта США по делимитации УА с применением критерия максимально допустимых разрывов по автодорогам и эта модель делимитации УА (с применением небольших необходимых корректировок) была взята за основу.

Для определения границ городской агломерации (МА) в условиях отсутствия данных о маятниковой трудовой миграции наиболее простым и точным аппроксимирующим методом является гравитационный, основанный на применении модели Рейли-Конверса. На основе анализа зарубежных подходов к делимитации МА наиболее обоснованным был признан опыт США по формированию комбинированных статистических ареалов (CSA).

Аппроксимация зависимости площади американских CSA от их населения позволила выявить связь предельного расстояния МА от центра агломерации с численностью населения ее ядра (УА). Она описывается степенной зависимостью корня четвертой степени, принятой за основу модели делимитащиии $M A$.

Дополнительно нами была предложена модель объединения смежных МА в объединенные метрополитенские ареалы (ОМА), т. е. модель делимитациии ОМА с применением гравитационного критерия.

В результате осуществленной широкомасштабной оценки российских агломераций по моделям делимитации УА, МА и ОМА была показана применимость, объективность, простота и практическая ценность предложенных моделей. Анализ размеров полученных российских МА показал хорошее приближение к размерам аналогичных по населению МА других стран, рассчитанных с применением критерия интенсивности маятниковой трудовой миграции.

Анализ результатов оценки состава и границ российских агломераций, их развитости за последнее десятилетие показал существенный рост крупных российских агломераций по сравнению с общим ростом населения в стране, в результате чего доля населения, проживающего в крупных российских агломерациях, выросла за второе десятилетие XXI века, в среднем, на 3\%. Отмечено, что наибольший рост населения происходит в субурбии крупных агломераций (в населенных пунктах, входящих в УА, но не являющихся его центром), главным образом, за счет притока населения из-за пределов агломерации. В то же время население российских агломераций за пределами субурбии (в периферии МА и в 
прочих МА, входящих в состав ОМА), как правило, сохраняется на прежнем уровне - там наблюдается баланс центростремительных и центробежных процессов в агломерации.

Результаты исследования могут иметь широкое применение:

- сравнение социально-экономических показателей агломераций и зон их влияния, корректировка на основе проведенного анализа государственной региональной политики;

- оптимальное изменение административно-территориального деления, формирование органов местного самоуправления, исходя из учета сложившихся агломераций;

- оптимизация бюджетного и тарифного планирования: нормирование, исходя из учета агломерационного эффекта затрат бюджетных учреждений, субъектов естественных монополий;

- развитие агломерационных объединений по единым генеральным планам, транспортное планирование и др.;

- совершенствование статистики, делающее возможным, в частности, сравнение разных стран и регионов по единой методике: оценку уровня урбанизации, сравнение агломераций, оценку и сравнение динамики населения крупных, средних и небольших агломераций, выработку критериев модели маятниковой трудовой миграции на основе ожидаемых данных всероссийской переписи населения 2020 г., оценку российских агломераций, как это сделано, в настоящем исследовании, и многое другое.

\section{ЛИТЕРАТУРА}

Антонов Е.В., Махрова А.Г. (2019). Крупнейшие городские агломерации и формы расселения надагломерационного уровня в России. Известия РАН. Серия географическая, 4, 31-45. URL: https://elibrary.ru/item.asp?id=39239323

Занадворов В.С., Занадворова А.В. (2003). Экономика города. Вводный курс: учебное пособие. М.: ИКЦ «Академкнига».

Ижгузина Н.Р. (2014). Подходы к делимитации городских агломераций. Дискуссия, 9(50), 44-52. URL: https://cyberleninka.ru/article/v/podhody-k-delimitatsii-gorodskih-aglomeratsiy

Лаппо Г.М. (1978). Развитие городских агломераций в СССР. М.: Наука.

Лаппо Г.М., Полян П.М., Селиванова Т.И. (2007). Агломерации России в XXI веке. Вестник Фонда регионального развития Иркутской области, 1, 45-52. URL: http://www.frrio.ru/uploads_files/Lappo.pdf

Лейзерович Е.Е. (2010). Сетка экономических микрорайонов России. Вариант 2008 года. Региональные исследования. 4(30), 14-28. URL: https://elibrary.ru/item.asp?id=15637765

Лимонов Л.Э. (2014) Региональная экономика и пространственное развитие. Т.1. М.: Юрайт.

Листенгурт Ф.М. (1975). Критерии выделения крупномасштабных агломераций в СССР. Известия Академии наук СССР, серия географическая, 6, 41-50. 
Малоян Г.А. (2012). К проблемам формирования городских агломераций. Архитектура и строительство России, 2, 83-85. URL: https://cyberleninka.ru/article/n/k-problemamformirovaniya-gorodskih-aglomeratsiy

Махрова А.Г., Бабкин Р.А. (2018). Анализ пульсаций системы расселения московской агломерации с использованием данных сотовых операторов. Региональные исследования, 2(60), Смоленский государственный университет, 68-78. URL: https://elibrary.ru/item.asp?id=35417472

Минэкономразвития (2018). Обосновывающие материалы к проекту Стратегии пространственного развития на период до 2025 года. Приложение к письму Минэкономразвития России от 27.07.2018 №21077-ВЖ/Д27и. URL: https://www.spsss.ru/assets/files/2018/v-nts_strategiya-prostranstvennogo-razvitiya.pdf

Монастырская М.Е., Песляк О.А. (2019). Методика определения границ городских агломераций. Вестник БГТУ им. В.Г. Шухова, 2, 111-121. URL: https://riorpub.com/en/storage/view/31904

Нефедова Т.Г., Аверкиева К.В., Махрова А.Г. (Ред.) (2016). Между домом и... домом. Возвратная пространственная мобильность населения России. М.: Новый Хронограф.

Пивоваров Ю.Л. (2002). Сжатие «экономической ойкумены» России. Мировая экономика и международные отношения, 4, 63-69.

Полян П.М. (2014). Территориальные структуры - урбанизация - расселение: теоретические подходы и методы изучения. М.: Новый хронограф.

Полян П.М., Заславский И.Н., Наймарк Н.И. (1988). Проблемы делимитации городских агломераций: сравнение и синтез ведущих методик. Проблемы территориальной организации пространства и расселения в урбанизированных районах. Свердловск, 2640.

Пузанов А., Попов Р. (2017). Подходы к оценке развитости городских агломераций. М.: Институт экономики города. URL: http://www.urbaneconomics.ru/sites/default/files/iue_press.pdf

Райсих А.Э. (2020). К вопросу об определении границ городских агломераций: мировой опыт и формулировка проблемы. Демографическое обозрение, том 7, № 1, 27-53. URL: https://demreview.hse.ru/article/view/10819/12136 (дата обращения 18.05.2020)

Росстат (2010). Публикация итогов Всероссийской переписи населения 2010 года. Т.1. Численность и размещение населения. 11. Численность населения России, федеральных округов, субъектов Российской Федерации, городских округов, муниципальных районов, городских и сельских поселений. URL: https://gks.ru/free_doc/new_site/perepis2010/croc/Documents/Vol1/pub-01-11.xlsx (дата обращения 12.05.2020).

Росстат (2019). Численность населения Российской Федерации по муниципальным образованиям на 1 января 2019 года, таблица 26-19. URL: https://www.gks.ru/compendium/document/13282 (дата обращения 12.05.2020).

Росстат (2020). Численность постоянного населения Российской Федерации по муниципальным образованиям на 1 января 2020 года. URL: https:/gks.ru/folder/12781 (раздел Информация, подраздел Оперативная информация, дата публикации 23.04.2020). 
Соколов С.Н. (2015). Агломерационные формы расселения Югры. Актуальные проблемы гуманитарных и естественных наук, 12-8, 61-66. URL: https://elibrary.ru/item.asp?id=25284020

Стрельников А.И., Семенова О.С. (2010). Варианты определения границ агломерации в современных условиях на основе анализа социальных и экономических связей с применением расчетного моделирования. Транспортное дело России, 8(81), 145-155. URL: https://elibrary.ru/item.asp?id=20137326

Укрстат (2011). Статистичний збірник "Чисельність наявного населення України на 1 січня 2011 року". Київ: ДКС. URL:

http://database.ukrcensus.gov.ua/PXWEB2007/ukr/publ_new1/2011/chnas.zip

Уляева А.Г. (2016). Разработка и апробация методики определения пространственной локализации агломерации (на материалах республики Башкортостан). Современная наука: актуальные проблемы теории и практики. Серия: экономика и право, 10, 48-54. URL: http://www.nauteh-journal.ru/files/74030711-81c9-405a-9ef7-c2cf65b992cb

Уляева А.Г., Мигранова Л.И. (2017). Исследование процессов маятниковой трудовой миграции в городской агломерации. Вестник Белгородского университета кооперации, экономики и права, 5 (66), 179-193. URL: https://www.elibrary.ru/item.asp?id=29962579

Шитова Ю.Ю., Шитов Ю.А. (2016). ГИС-мониторинг маятниковой трудовой миграции как задача регионального управления. Современные технологии управления, 2 (62), 49-60. URL: https://elibrary.ru/item.asp?id=25512255

Шитова Ю.Ю., Шитов Ю.А., Власов Д.Н. (2019). Цифровой мониторинг транспорта Московской агломерации с помощью геоинформационных систем. Вестник Университета Правительства Москвы, 3 (45), 54-59. URL: https://elibrary.ru/item.asp?id=41192517

Юсин Г.С., Раев Ю.В., Алексеева А.А. (2015). Совершенствование системы расселения ключевое направление стратегии пространственного развития России. Градостроительство, 2, 9-28. URL: https://elibrary.ru/item.asp?id=24373787 


\section{ПРИЛОЖЕНИЕ}

Таблица П-1. Характеристики аппроксимирующих степенных функций различных агломераций мира

\begin{tabular}{|c|c|c|c|c|c|c|c|c|c|c|c|c|}
\hline \multirow[t]{2}{*}{ Страна } & \multirow{2}{*}{ 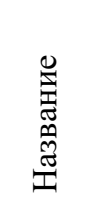 } & \multirow{2}{*}{ 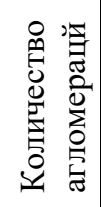 } & \multicolumn{3}{|c|}{$\begin{array}{c}\text { Население агломераций в } \\
\text { выборке, тыс. чел. }\end{array}$} & \multirow{2}{*}{$\begin{array}{c}\text { Дата } \\
\text { переписи, } \\
\text { оценки }\end{array}$} & \multicolumn{3}{|c|}{$\begin{array}{c}\text { Показатели } \\
\text { аппроксимирующей } \\
\text { степенной функции }\end{array}$} & \multicolumn{3}{|c|}{$\begin{array}{c}\text { Расчетные расстояния, км для } \\
\text { численности населения агломерации: }\end{array}$} \\
\hline & & & мин. & сред. & макс. & & $\mathrm{k}$ & $\mathrm{v}$ & $\mathrm{R} 2$ & $\begin{array}{c}50 \text { тыс. } \\
\text { чел. }\end{array}$ & $\begin{array}{c}1 \text { млн } \\
\text { чел. }\end{array}$ & $\begin{array}{c}20 \text { млн } \\
\text { чел. }\end{array}$ \\
\hline \multicolumn{13}{|c|}{ 1) Агломерации разных стран } \\
\hline Албания & Aggl. & 17 & 23,1 & 101,7 & 705,4 & 01.10 .2011 & 1,86 & 3,03 & 0,7042 & 6,77 & 18,20 & 48,90 \\
\hline Австрия & Aggl. & 38 & 16,1 & 122,7 & 2221,5 & 01.01 .2019 & 2,46 & 3,95 & 0,529 & 6,64 & 14,17 & 30,28 \\
\hline Бельгия & Aggl. & 19 & 58,3 & 278,7 & 1815,1 & 01.01.2019 & 1,22 & 2,86 & 0,7867 & 4,78 & 13,61 & 38,78 \\
\hline Франция & Aggl. & 2225 & 1,9 & 22,4 & 10734 & 01.01 .2019 & 1,95 & 3,40 & 0,4911 & 6,15 & 14,87 & 35,91 \\
\hline Ирландия & Aggl. & 843 & 0,09 & 3,8 & 1110,6 & 24.04 .2016 & 0,58 & 2,58 & 0,8079 & 2,62 & 8,38 & 26,78 \\
\hline Швейцария & Aggl. & 49 & 21,5 & 127,5 & 1384,3 & 01.01.2019 & 1,18 & 2,45 & 0,5739 & 5,83 & 19,76 & 67,00 \\
\hline Великобритания & Aggl. & 131 & 46,7 & 389,2 & 14247,9 & 01.07 .2018 & 0,68 & 2,38 & 0,8675 & 3,51 & 12,38 & 43,64 \\
\hline Австралия & BUA & 124 & 9,8 & 155,5 & 4321,5 & 01.07.2018 & 1,05 & 2,50 & 0,8342 & 5,05 & 16,75 & 55,59 \\
\hline Эстония & BUA & 369 & 0,2 & 3 & 391,3 & 01.01 .2012 & 0,83 & 3,28 & 0,726 & 2,74 & 6,85 & 17,08 \\
\hline Германия & BUA & 1704 & 4,6 & 36,7 & 4506,4 & 01.01.2019 & 0,51 & 2,36 & 0,8614 & 2,68 & 9,52 & 33,80 \\
\hline Нидерланды & BUA & 179 & 14,4 & 65,2 & 1114,8 & 01.01 .2018 & 0,33 & 2,18 & 0,891 & 1,99 & 7,87 & 31,17 \\
\hline Норвегия & BUA & 62 & 9,8 & 50,7 & 1019,5 & 01.01.2019 & 0,49 & 2,31 & 0,9425 & 2,69 & 9,86 & 36,10 \\
\hline Великобритания & BUA & 153 & 50,2 & 287,8 & 10620,1 & 01.07 .2018 & 0,34 & 2,14 & 0,9595 & 2,10 & 8,53 & 34,59 \\
\hline США & BUA & 3592 & 2,5 & 70,4 & 18351,3 & 01.04 .2010 & 0,78 & 2,15 & 0,923 & 4,80 & 19,35 & 77,96 \\
\hline Австралия & UA & 101 & 10,9 & 214,7 & 4835,2 & 01.07.2018 & 2,30 & 2,84 & 0,7026 & 9,09 & 26,08 & 74,79 \\
\hline Канада & UA & 213 & 9,8 & 122,7 & 5429,5 & 10.05 .2016 & 0,67 & 2,37 & 0,9155 & 3,50 & 12,38 & 43,78 \\
\hline Чили & UA & 77 & 18,8 & 177,4 & 6160 & 19.04.2017 & 0,37 & 2,26 & 0,8938 & 2,10 & 7,94 & 29,95 \\
\hline Дания & UA & 123 & 5 & 31,5 & 1320,6 & 01.01 .2019 & 0,55 & 2,42 & 0,9051 & 2,79 & 9,64 & 33,30 \\
\hline Финляндия & UA & 51 & 10,2 & 72,3 & 1286,2 & 01.01.2019 & 1,09 & 2,80 & 0,8841 & 4,41 & 12,87 & 37,57 \\
\hline Германия & UA & 180 & 36,9 & 293,4 & 5612,3 & 01.01 .2019 & 0,54 & 2,33 & 0,9203 & 2,90 & 10,46 & 37,74 \\
\hline Новая Зеландия & UA & 123 & 2,4 & 32,7 & 1402 & 01.07 .2019 & 0,87 & 2,55 & 0,8556 & 4,04 & 13,07 & 42,26 \\
\hline Португалия & UA & 339 & 0,4 & 22,4 & 547,8 & 21.03.2011 & 1,66 & 4,42 & 0,231 & 4,03 & 7,95 & 15,66 \\
\hline Швеция & UA & 126 & 5,1 & 51,9 & 1735 & 01.01 .2019 & 0,65 & 2,63 & 0,8546 & 2,87 & 8,97 & 28,09 \\
\hline
\end{tabular}




\begin{tabular}{|c|c|c|c|c|c|c|c|c|c|c|c|c|}
\hline Швейцария & UA & 77 & 5,8 & 69,7 & 1099,8 & 01.01 .2019 & 1,76 & 4,01 & 0,3745 & 4,66 & 9,83 & 20,73 \\
\hline США & UA & 488 & 44 & 450,8 & 18351,3 & 01.04 .2010 & 0,91 & 2,29 & 0,8894 & 4,98 & 18,39 & 67,85 \\
\hline Канада & MA & 152 & 11,3 & 203,8 & 6341,9 & 01.07 .2018 & 2,88 & 2,53 & 0,3145 & 13,47 & 43,93 & 143,31 \\
\hline Мексика & MA & 74 & 113,1 & 1014,6 & 20892,7 & 15.03 .2015 & 6,09 & 4,25 & 0,1757 & 15,30 & 30,97 & 62,71 \\
\hline США (восток) & MSA & 716 & 12,6 & 325 & 19303,8 & 01.07.2018 & 10,28 & 4,71 & 0,4824 & 23,61 & 44,62 & 84,34 \\
\hline США & MSA & 938 & 12,6 & 332,8 & 19303,8 & 01.07 .2018 & 13,31 & 5,51 & 0,2534 & 27,07 & 46,63 & 80,30 \\
\hline США (восток) & CSA & 401 & 12,6 & 580,4 & 22679,9 & 01.07 .2018 & 9,89 & 4,00 & 0,719 & 26,30 & 55,62 & 117,60 \\
\hline США & $\mathrm{CSA}$ & 563 & 12,6 & 554,3 & 22679,9 & 01.07 .2018 & 13,93 & 4,72 & 0,4264 & 31,87 & 60,09 & 113,28 \\
\hline \multicolumn{13}{|c|}{ 2) Метрополитенские ареалы численностью свыше 250 тысяч жителей } \\
\hline Бенилюкс & MA & 23 & 273,3 & 750,5 & 2717,4 & 01.01 .2017 & 1,60 & 2,68 & 0,468 & 6,90 & 21,10 & 64,52 \\
\hline Франция и Швейцария & MA & 46 & 272,6 & 834,2 & 12006,9 & 01.01 .2017 & 4,72 & 3,80 & 0,3223 & 13,24 & 29,15 & 64,19 \\
\hline Германия и Австрия & MA & 73 & 252,6 & 828,3 & 5142,2 & 01.01 .2017 & 3,18 & 3,13 & 0,3662 & 11,09 & 28,85 & 75,06 \\
\hline Италия и Греция & MA & 24 & 281,4 & 1202,2 & 5101,1 & 01.01 .2017 & 2,50 & 3,26 & 0,5346 & 8,29 & 20,78 & 52,10 \\
\hline Польша, Литва, Латвия, Эстония & MA & 20 & 284,5 & 808,7 & 3132,7 & 01.01 .2017 & 3,44 & 3,09 & 0,5628 & 12,20 & 32,14 & 84,68 \\
\hline Чехия, Словакия, Венгрия, Словения & MA & 13 & 256 & 764,6 & 2965,9 & 01.01 .2017 & 6,63 & 4,39 & 0,6209 & 16,14 & 31,91 & 63,09 \\
\hline Испания и Португалия & MA & 28 & 257,2 & 1018,7 & 6633,3 & 01.01 .2017 & 2,51 & 3,11 & 0,5069 & 8,84 & 23,17 & 60,70 \\
\hline Великобритания и Ирландия & MA & 48 & 251,2 & 974,8 & 11984,4 & 01.01 .2017 & 1,70 & 2,66 & 0,3571 & 7,41 & 22,85 & 70,46 \\
\hline Европа 38 & MA & 291 & 251,2 & 889,1 & 12006,9 & 01.01 .2017 & 3,61 & 3,48 & 0,2697 & 11,14 & 26,38 & 62,46 \\
\hline Австралия & MA & 10 & 285,4 & 1748,6 & 5029,7 & 01.01 .2017 & 2,09 & 2,47 & 0,6592 & 10,16 & 34,09 & 114,43 \\
\hline Корея & MA & 19 & 277,6 & 2219,6 & 24048,8 & 01.01 .2017 & 3,70 & 4,40 & 0,5148 & 9,01 & 17,78 & 35,10 \\
\hline Япония & MA & 53 & 263 & 1827,5 & 35385,8 & 01.01 .2017 & 4,39 & 4,16 & 0,4716 & 11,23 & 23,08 & 47,41 \\
\hline Канада & MA & 16 & 258,3 & 1454,5 & 6894,7 & 01.01 .2017 & 6,96 & 3,69 & 0,3314 & 20,09 & 45,26 & 101,94 \\
\hline Мексика & MA & 63 & 278,7 & 1210,5 & 20554 & 01.01 .2017 & 6,41 & 4,53 & 0,118 & 15,19 & 29,42 & 56,96 \\
\hline Чили & MA & 9 & 263,5 & 1268,8 & 7181,5 & 01.01 .2017 & 8,82 & 5,05 & 0,1141 & 19,15 & 34,65 & 62,72 \\
\hline США & CSA & 162 & 249,3 & 1435,7 & 20254 & 01.01 .2017 & 7,64 & 3,72 & 0,3303 & 21,85 & 48,84 & 109,17 \\
\hline 3) Агломерации России & & & & & & & & & & & & \\
\hline \multirow{2}{*}{$\begin{array}{l}\text { По СПР (Минэкономразвития 2018) } \\
\text { по минимальному варианту } \\
\text { (Антонов, Махрова 2019) }\end{array}$} & MA & 40 & 637 & 1857 & 21073 & 01.01 .2019 & 5,18 & 2,98 & 0,53 & 19,23 & 52,50 & 143,27 \\
\hline & MA & 36 & 585 & 1652 & 15076 & 01.01 .2019 & 11,17 & 5,38 & 0,1428 & 23,11 & 40,32 & 70,35 \\
\hline $\begin{array}{l}\text { По базовому варианту } \\
\text { (Антонов, Махрова 2019) }\end{array}$ & MA & 36 & 696 & 1966 & 21014 & 01.01 .2019 & 6,59 & 3,29 & 0,5175 & 21,63 & 53,75 & 133,62 \\
\hline $\begin{array}{l}\text { По расширенному варианту } \\
\text { (Антонов, Махрова 2019) }\end{array}$ & MA & 36 & 731 & 2061 & 21064 & 01.01 .2019 & 11,51 & 3,99 & 0,4701 & 30,67 & 64,98 & 137,67 \\
\hline
\end{tabular}

${ }^{38}$ Включая вышеперечисленные агломерации европейских стран + агломерации 5 скандинавских стран (Финляндия, Швеция, Норвегия, Исландия, Дания). 
По ЭМР Лейзеровича (Антонов, Махрова 2019)

36

719

2021

19088

01.01.2019

50,25

15,90

0,0258

77,59

93,68

Итоговый результат оценки автором статьи агломераций России:

Метрополитенские ареалы России

$\begin{array}{lllll}\text { MA } & 316 & 50 & 372 & 20190\end{array}$

01.01 .2019

$8,15 \quad 4,12 \quad 0,5705$

21,07

43,61

90,26

ареалы России

OMA 253

$50 \quad 474 \quad 20546$

$\begin{array}{llll}01.01 .2019 & 7,97 & 3,82 & 0,6925\end{array}$

22,17

48,56

106,33

Источники:

1) Агломерации разных стран: CITY POPULATION. Population statistics for countries, administrative divisions, cities, urban areas and agglomerations - interactive maps and charts. (C) Thomas Brinkhoff. URL: https://www.citypopulation.de/ (дата обращения 12.05.2020),

2) Метрополитенские ареаль численностью свыше 250 тыс. жителей: OECD. Metropolitan explorer. URL: https://measuringurban.oеcd.org/\#story=0 (дата обращения 12.05.2020);

3) Агломераџии России: (Минэкономразвития 2018; Антонов, Махрова 2019), оценка автором статьи населения по данным (Росстат 2019) и площадей агломерачий.

Таблица П-2. Урбанизированные ареалы (УА) России численностью не менее 500 тыс. человек

\begin{tabular}{|c|c|c|c|c|c|c|c|}
\hline \multirow{2}{*}{ № } & \multirow{2}{*}{ УA } & \multicolumn{2}{|c|}{$\begin{array}{l}\text { Население, } \\
\text { тыс. человек }\end{array}$} & \multicolumn{3}{|c|}{$\begin{array}{l}\text { Изменение населения, } 2020 \text { г. к } \\
2010 \text { г., \% }\end{array}$} & \multirow{2}{*}{$\begin{array}{c}\text { Состав УА: } \\
\text { населенные пункты свыше } 10 \text { тыс. человек, входящие в состав УА }\end{array}$} \\
\hline & & 2010 г. & 2020 г. & $\begin{array}{c}\text { главный } \\
\text { город }\end{array}$ & субурбия ${ }^{39}$ & УA & \\
\hline 1 & Москва $^{40}$ & 15111 & 16817 & 8,0 & 22,7 & 11,3 & $\begin{array}{l}\text { Балашиха, Подольск, Химки, Мытищи, Королёв, Люберцы, } \\
\text { Красногорск, Домодедово } 41 \text {, Одинцово, Щёлково, Раменское, } \\
\text { Долгопрудный, Реутов, Пушкино, Жуковский, Лобня } 42 \text { Ивантеевка, } \\
\text { Видное, Фрязино, Дзержинский, Котельники, Нахабино, } \\
\text { Краснознаменск, Апрелевка, Дедовск, Томилино, Власиха, Лосино- } \\
\text { Петровский, Малаховка, Старая Купавна, Красково, Калининец, } \\
\text { Электроугли, Монино, Октябрьский, Голицыно, Удельная, Селятино, } \\
\text { Свердловский, ВНИИСОК, Большие Вязёмы, Развилка, Ильинский, } \\
\text { Островцы, Быково, Андреевка, Обухово }\end{array}$ \\
\hline
\end{tabular}

${ }^{39}$ Населенные пункты, за исключением главного города, входящие в состав УА.

${ }^{40}$ Кроме Троицкого административного округа и Десёновского поселения.

${ }^{41}$ Кроме микрорайонов Барыбино и Белые Столбы.

42 Кроме микрорайона Луговая (входит в УА Некрасовский). 


\begin{tabular}{|c|c|c|c|c|c|c|c|}
\hline \multirow[t]{2}{*}{2} & Санкт-Петербург ${ }^{43}$ & 5013 & 5690 & 10,6 & 118,9 & 13,5 & \multirow[t]{2}{*}{$\begin{array}{l}\text { Мурино, Сертолово, Кудрово, Отрадное, Коммунар, Новое Девяткино, } \\
\text { Бугры, Старая, Янино-1, имени Свердлова, Тельмана, Кузьмоловский }\end{array}$} \\
\hline & Москва и Санкт-Петербург & 20124 & 22507 & 8,8 & 26,4 & 11,8 & \\
\hline 3 & Новосибирск ${ }^{44}$ & 1549 & 1730 & 10,3 & 39,6 & 11,7 & Обь, Краснообск, Кольцово \\
\hline 4 & Екатеринбург & 1548 & 1718 & 10,6 & 13,1 & 11,0 & Верхняя Пышма, Березовский, Среднеуральск, Арамиль \\
\hline 5 & Нижний Новгород & 1378 & 1400 & 0,1 & 15,4 & 1,5 & Кстово \\
\hline 6 & Челябинск & 1305 & 1399 & 5,9 & 15,3 & 7,2 & Копейск \\
\hline 7 & Казань & 1197 & 1338 & 10,0 & 50,7 & 11,8 & Васильево, Высокая Гора, Осиново \\
\hline 8 & Самара $^{45}$ & 1273 & 1284 & $-0,7$ & 17,8 & 0,9 & $\begin{array}{l}\text { Новокуйбышевск, Придорожный, Стройкерамика, Смышляевка, Усть- } \\
\text { Кинельский, Алексеевка }\end{array}$ \\
\hline 9 & Ростов-на-Дону & 1164 & 1230 & 4,5 & 22,3 & 5,6 & Батайск, Аксай \\
\hline 10 & $\mathrm{Oмск}^{46}$ & 1161 & 1170 & 0,0 & 109,7 & 0,7 & \\
\hline 11 & Воронеж${ }^{47}$ & 1068 & 1168 & 8,5 & 18,6 & 9,4 & Новая Усмань, Семилуки \\
\hline 12 & Саратов & 1121 & 1147 & 0,0 & 9,1 & 2,3 & Энгельс, Приволжский \\
\hline 13 & Красноярск & 1013 & 1141 & 12,3 & 19,6 & 12,6 & Березовка \\
\hline 14 & $П_{е р м ь}^{48}$ & 1031 & 1107 & 6,5 & 32,1 & 7,5 & Кондратово \\
\hline 15 & $\mathrm{Y} \phi \mathrm{a}^{49}$ & 1005 & 1071 & 6,3 & нет $^{50}$ & 6,5 & \\
\hline 16 & Краснодар & 851 & 1062 & 25,2 & 22,5 & 24,9 & Яблоновский, Елизаветинская \\
\hline 17 & Волгоград ${ }^{51}$ & 1054 & 1045 & $-1,2$ & 9,9 & $-0,9$ & Городище \\
\hline & 15 УА-миллиоников & 17719 & 19010 & 6,3 & 19,4 & 7,3 & \\
\hline 18 & Махачкала & 805 & 872 & 5,5 & 15,1 & 8,3 & $\begin{array}{l}\text { Каспийск, Ленинкент, Тарки, Семендер, Альбурикент, Новый Хушет, } \\
\text { Шамхал, Шамхал-Термен, Новый Кяхулай }\end{array}$ \\
\hline 19 & Тюмень & 623 & 833 & 33,5 & 43,3 & 33,8 & \\
\hline 20 & Иркутск & 678 & 752 & 6,1 & 42,7 & 10,9 & Шелехов, Маркова \\
\hline 21 & Владивосток & 718 & 739 & 2,5 & 4,9 & 2,9 & Артем ${ }^{52}$, Трудовое \\
\hline
\end{tabular}

${ }^{43}$ Кроме Курортного района (без поселка Песочный), города Кронштадт, поселка Лисий Нос.

${ }^{44}$ Кроме микрорайонов Пашино, Кирово +Геологов (входит в УА Бердск).

${ }^{45}$ Кроме микрорайонов Берёза, Прибрежный, Красная Глинка, Управленческий, Южный.

${ }^{46}$ Кроме микрорайонов Береговой, Входной, Крутая Горка

${ }^{47}$ Кроме микрорайона Краснолесный.

48 Кроме микрорайона Новые Ляды.

${ }^{49}$ Кроме Дёмского района и микрорайона Шакша.

50 Здесь и далее для случая, если численность населения главного города превышает численность населения УА.

${ }^{51}$ Кроме микрорайонов Сарпинский, Южный, Горный, Водный, Гули Королевой, Майский.

52 Кроме микрорайона Заводской. 


\begin{tabular}{|c|c|c|c|c|c|c|c|}
\hline 22 & Тольятти ${ }^{53}$ & 727 & 721 & $-2,8$ & 192,9 & $-0,8$ & Подстепки \\
\hline 23 & Барнаул & 672 & 699 & 3,3 & 11,8 & 4,0 & Южный, Власиха \\
\hline 24 & Ижевск & 654 & 683 & 3,3 & 35,1 & 4,5 & \\
\hline 25 & Чебоксары & 616 & 664 & 9,7 & 2,7 & 7,8 & Новочебоксарск, Кугеси \\
\hline 26 & Ульяновск & 650 & 664 & 2,1 & 3,0 & 2,1 & Ишеевка \\
\hline 27 & Хабаровск & 612 & 657 & 6,9 & 16,3 & 7,5 & \\
\hline 28 & Ярославль & 621 & 644 & 2,9 & 18,8 & 3,6 & \\
\hline 29 & Оренбург & 573 & 618 & 4,4 & 81,6 & 7,7 & Нежинка \\
\hline 30 & Тула & 629 & 604 & $-5,2$ & 1,1 & $-3,9$ & Щекино \\
\hline 31 & Томск & 540 & 599 & 9,9 & 44,5 & 10,9 & Зональная Станция \\
\hline 32 & Астрахань & 572 & 592 & 1,8 & 19,5 & 3,4 & \\
\hline 33 & Рязань ${ }^{54}$ & 558 & 578 & 2,7 & 17,3 & 3,6 & Рыбное \\
\hline 34 & Ставрополь & 496 & 574 & 13,1 & 26,6 & 15,7 & Михайловск, Надежда \\
\hline 35 & Пенза & 541 & 561 & 0,6 & 75,7 & 3,8 & Засечное, Бессоновка \\
\hline 36 & Набережные Челны & 524 & 549 & 4,0 & 42,9 & 4,8 & \\
\hline 37 & Калининград & 475 & 547 & 13,3 & 36,0 & 15,3 & Гурьевск \\
\hline 38 & Липецк & 537 & 541 & $-0,1$ & 15,3 & 0,8 & Грязи \\
\hline 39 & Киров ${ }^{56}$ & 492 & 539 & 9,4 & 10,0 & 9,4 & \\
\hline 40 & Кемерово ${ }^{57}$ & 526 & 537 & 4,4 & нет & 2,1 & \\
\hline 41 & Курск & 468 & 509 & 9,1 & 6,6 & 8,8 & \\
\hline \multirow[t]{2}{*}{42} & Белгород & 444 & 504 & 10,6 & 25,9 & 13,6 & Дубовое, Северный \\
\hline & 25 УА-полумиллиоников & 14751 & 15782 & 5,8 & 18,3 & 7,0 & \\
\hline \multirow{2}{*}{\multicolumn{2}{|c|}{$\begin{array}{l}\text { Итого по } 42 \text { крупным УА } \\
\text { Остальное население РФ* }\end{array}$}} & 52594 & 57298 & 7,0 & 23,0 & 8,9 & \\
\hline & & 92607 & 89451 & & & $-3,4$ & \\
\hline
\end{tabular}

Справочно: Прочие УА численностью не менее 250 тыс. человек, входящие в агломерации (МА и/или ОМА) не менее 500 тыс. человек:

\begin{tabular}{|c|c|c|c|c|c|c|}
\hline Улан-Удэ & 431 & 493 & 8,6 & 105,8 & 14,5 & Сотниково \\
\hline Симферополь* & 478 & 487 & 1,7 & 2,3 & 1,9 & \\
\hline Новокузнецк ${ }^{58}$ & 468 & 468 & 0,3 & нет & 0,0 & \\
\hline Иваново & 469 & 467 & $-0,9$ & 2,5 & $-0,5$ & Кохма \\
\hline Брянск & 461 & 453 & $-3,1$ & 10,1 & $-1,8$ & \\
\hline
\end{tabular}

${ }^{53}$ Кроме микрорайона Поволжский.

${ }^{54}$ Кроме микрорайона Солотча.

55 Кроме микрорайона Монтажный (входит в УА Заречный).

56 Кроме микрорайонов Лянгасово, Победилово.

${ }^{57}$ Кроме микрорайонов Кедровка, Лесная Поляна, Промышленновский.

${ }^{58}$ Кроме Новоильинского района, микрорайонов Абагур, Абагуровский разъезд, Листвяги, Притомский. 


\begin{tabular}{|c|c|c|c|c|c|c|}
\hline Тверь & 422 & 443 & 5,3 & $-0,4$ & 5,1 & \\
\hline Владикавказ & 392 & 381 & $-2,6$ & $-4,0$ & $-2,9$ & Заводской, Сунжа (село), Ногир, Октябрьское \\
\hline Севастополь* 59 & 307 & 367 & 17,9 & нет & 19,4 & \\
\hline Орёл & 370 & 363 & $-2,8$ & 4,4 & $-1,8$ & Знаменка \\
\hline Саранск & 329 & 354 & 7,8 & 6,3 & 7,7 & \\
\hline Владимир ${ }^{60}$ & 339 & 351 & 3,3 & нет & 3,4 & \\
\hline Нижний Тагил & 362 & 349 & $-3,5$ & $-28,3$ & $-3,5$ & \\
\hline Смоленск ${ }^{61}$ & 332 & 348 & $-0,4$ & 344,0 & 4,8 & \\
\hline Грозный & 308 & 347 & 12,6 & 13,4 & 12,7 & Гикало \\
\hline Архангельск ${ }^{62}$ & 345 & 344 & $-0,5$ & нет & $-0,3$ & \\
\hline Назрань & 282 & 344 & 31,0 & 17,6 & 22,0 & $\begin{array}{l}\text { Сунжа (город), Карабулак, Экажево, Троицкая, Плиево, Магас, } \\
\text { Барсуки }\end{array}$ \\
\hline Волжский & 345 & 341 & $-1,1$ & 0,7 & $-1,0$ & Средняя Ахтуба \\
\hline Тамбов & 325 & 338 & 4,3 & 3,5 & 4,2 & Строитель \\
\hline Калуга ${ }^{63}$ & 330 & 336 & 1,3 & 97,7 & 1,9 & \\
\hline Новороссийск & 267 & 303 & 13,6 & 13,4 & 13,6 & \\
\hline Нальчик & 303 & 302 & $-0,3$ & $-0,9$ & $-0,4$ & Нартан, Шалушка, Хасанья \\
\hline Кострома & 291 & 300 & 3,0 & 5,0 & 3,2 & \\
\hline Стерлитамак & 284 & 293 & 1,1 & 55,1 & 3,1 & \\
\hline Таганрог & 295 & 288 & $-3,5$ & 4,3 & $-2,5$ & \\
\hline Электросталь & 274 & 281 & 0,5 & 4,7 & 2,3 & Ногинск \\
\hline Сочи ${ }^{64}$ & 218 & 274 & 29,2 & нет & 25,7 & \\
\hline Армавир & 264 & 264 & 0,1 & $-0,2$ & 0,0 & Новокубанск \\
\hline Прокопьевск & 286 & 258 & $-9,4$ & $-11,0$ & $-9,9$ & Киселёвск ${ }^{65}$ \\
\hline Пятигорск 66 & 251 & 255 & 3,8 & $-1,1$ & 1,7 & Лермонтов, Свободы \\
\hline Шахты & 262 & 250 & $-4,1$ & $-8,5$ & $-4,4$ & Каменоломни \\
\hline
\end{tabular}

${ }^{59}$ Кроме Андреевского, Верхнесадовского, Качинского, Орлиновского, Терновского муниципальных образований, Балаклавы, Инкермана, Северной стороны, микрорайонов Первомайское, Флотское, 1-го отделение Золотой Балки, Морозовка, Оборонное, Хмельницкое, Черноречье.

${ }^{60}$ Кроме микрорайонов Лесной, Лунево, Оргтруд, Сельцо, Ширманиха, Энергетик, Юрьевец.

${ }^{61}$ Кроме микрорайонов Красный Бор, Гнёздово.

62 Кроме Цигломенского округа, микрорайонов Лесной Порт, Конвейер, Лесозавод 29, Хабарка и Кегостров.

${ }^{63}$ Кроме микрорайонов Куровской, Плетеневка, Резвань (все входят в УА Воротынск).

${ }^{64}$ Кроме Адлерского района, Лазаревского района (кроме Дагомыса), части Хостинского района от Малого Ахуна до Кудепсты.

65 Кроме микрорайона Красный Камень.

${ }^{66}$ Кроме микрорайона Энергетик (входит в УА Иноземцево). 


\begin{tabular}{lllrrrr} 
Новомосковск $^{67}$ & 261 & 244 & $-6,9$ & $-5,8$ & $-6,4$ & Донской $^{68}$, Узловая \\
Хасавюрт & 155 & 174 & 10,6 & 18,4 & 11,8 & \\
\hline
\end{tabular}

Источник: Расчеты автора на основе данных: (Росстат 2010, 2020).

Примечание: * - Расчеты проведены в том числе с использованием данных для населения Крыма и Севастополя: (Укрстат 2011).

Таблица П-3. Метрополитенские ареалы России численностью не менее 500 тыс. человек

\begin{tabular}{c|c|c|c|c|c|}
\hline \multirow{2}{*}{ № } & MA $^{69}$ & \multicolumn{2}{|c|}{$\begin{array}{c}\text { Население, } \\
\text { тыс. человек }\end{array}$} & \multicolumn{3}{|c|}{ Изменение населения, 2020 г. к } & \multicolumn{2}{|c|}{2010 г., \% } \\
\cline { 3 - 7 } & & 2010 г. 2020 г. & УА & $\begin{array}{c}\text { периферия } \\
\text { МА }\end{array}$ & МА \\
\hline
\end{tabular}

Состав МА:

УА свыше 10 тыс. человек, входящие в состав $\mathrm{MA}^{70}$

Электросталь *, Обнинск (Малоярославец, Балабаново, Боровск, Белоусово, Ермолино), Коломна, Сергиев Посад (Хотьково), Серпухов, Орехово-Зуево, Воскресенск, Чехов, Троицк (поселение Москвы), Дмитров, Клин, Егорьевск, Павловский Посад, Наро-Фоминск, Ступино,

1 Москва - Электросталь

18541

20345

11,3

2 Санкт-Петербург
6460
Солнечногорск, Лыткарино, Кашира, Истра, Можайск, Бронницы,
Белоозёрский, Кубинка, Софрино, Протвино, Луховицы, Ликино-Дул

2,9

Белоозёрский, Кубинка, Софрино, Протвино, Луховицы, Ликино-Дулёво,

(Краснозаводск), Звенигород, Барыбино (мкрн. г. Домодедово),

Некрасовский, Электроизолятор, Пущино, Электрогорск, Поварово, Киевский (поселение Москвы), Черноголовка, Тучково, Покров, Белые Столбы (мкрн. г. Домодедово), Яхрома, Жуков, Руза, Михнево, Запрудня, Фряново, Кременки, Высоковск, Дрезна, Молоково, Таруса, Алачково, Новопетровское, Глебовский

Гатчина, Всеволожск, Сестрорецк (город в составе Санкт-Петербурга), Кировск (Шлиссельбург), Кронштадт (город в составе Санкт-Петербурга), Никольское (Ульяновка), Тосно, Лесколово, Зеленогорск (город в составе

${ }^{67}$ Кроме микрорайона Сокольники.

${ }^{68}$ Кроме микрорайонов Комсомольский, Руднев, Шахтёрский.

69 Указан главный город и УА свыше 250 тыс. человек.

${ }^{70}$ В скобках указаны населенные пункты свыше 10 тыс. человек, входящие в соответствующий УА, не указанные в таблице П2. 


\begin{tabular}{|c|c|c|c|c|c|c|c|}
\hline & & & & & & & Агалатово, имени Морозова, Мга \\
\hline & Москва и Санкт-Петербург & 24279 & 26805 & 11,8 & 3,4 & 10,4 & \\
\hline 3 & Екатеринбург & 1997 & 2160 & 11,0 & $-1,3$ & 8,2 & $\begin{array}{l}\text { Первоуральск, Полевской, Ревда, Заречный (Белоярский), Сысерть, } \\
\text { Дегтярск }\end{array}$ \\
\hline 4 & Новосибирск & 1914 & 2109 & 11,7 & 3,7 & 10,2 & $\begin{array}{l}\text { Бердск, Искитим, Пашино (мкрн. Новосибирска), Линево, Коченево, } \\
\text { Колывань, Криводановка, Прокудское, Мошково }\end{array}$ \\
\hline 5 & Нижний Новгород & 2004 & 2000 & 1,5 & $-4,0$ & $-0,2$ & Дзержинск, Бор, Балахна, Богородск, Заволжье, Городец, Володарск \\
\hline 6 & Ростов-на-Дону & 1760 & 1853 & 5,6 & 4,7 & 5,3 & $\begin{array}{l}\text { Новочеркасск }{ }^{71} \text {, Батайск, Азов (Кулешовка), Чалтырь, Кривянская, } \\
\text { Самарское, Пешково }\end{array}$ \\
\hline 7 & Казань & 1482 & 1637 & 11,8 & 4,9 & 10,4 & Зеленодольск, Волжск, Пестрецы, Лаишево \\
\hline 8 & Челябинск & 1545 & 1632 & 7,2 & $-3,0$ & 5,6 & Коркино (Роза), Еманжелинск, Красногорский, Аргаяш, Первомайский \\
\hline 9 & Самара & 1582 & 1603 & 0,9 & 3,1 & 1,3 & $\begin{array}{l}\text { Чапаевск, Красная Глинка (микрорайон Самары), Кинель, Рощинский, } \\
\text { Новосемейкино, Красный Яр, Прибрежный (микрорайон Самары) }\end{array}$ \\
\hline 10 & Волгоград - Волжский & 1558 & 1542 & $-0,9$ & $-1,4$ & $-1,0$ & $\begin{array}{l}\text { Волжский *, Краснослободск, Ленинск, Дубовка, Светлый Яр } \\
\text { Динская, Северская, Афипский, Новотитаровская, Ильский, Энем, }\end{array}$ \\
\hline 11 & Краснодар & 1213 & 1460 & 24,9 & 9,8 & 20,3 & $\begin{array}{l}\text { Медведовская, Адыгейск, Марьянская, Васюринская, Старокорсунская, } \\
\text { Пластуновская, Старомышастовская, Черноморский, Нововеличковская }\end{array}$ \\
\hline 12 & Уфа & 1301 & 1419 & 6,5 & 17,7 & 9,1 & $\begin{array}{l}\text { Дёма (район Уфы), Благовещенск, Иглино, Шакша (мкрн. Уфы), Чишмы, } \\
\text { Кармаскалы, Алкино-2, Булгаково, Авдон }\end{array}$ \\
\hline 13 & Красноярск & 1224 & 1366 & 12,6 & 7,2 & 11,7 & Железногорск (Сосновоборск), Дивногорск, Емельяново \\
\hline 14 & Омск & 1351 & 1359 & 0,7 & 0,0 & 0,6 & Береговой (микрорайон Омска), Таврическое, Лузино, Любинский \\
\hline 15 & Воронеж & 1244 & 1340 & 9,4 & $-2,6$ & 7,7 & Нововоронеж, Рамонь, Воля, Хохольский \\
\hline 16 & Пермь & 1193 & 1273 & 7,5 & 1,8 & 6,7 & Краснокамск, Полазна, Звёздный, Новые Ляды (микрорайон Перми) \\
\hline 17 & Саратов & 1214 & 1241 & 2,3 & 1,8 & 2,3 & Татищево (Светлый) \\
\hline 18 & Иркутск & 1090 & 1167 & 10,9 & 0,9 & 7,1 & Ангарск, Усолье-Сибирское, Хомутово, Белореченский \\
\hline 19 & Грозный & 996 & 1164 & 12,7 & 18,6 & 16,8 & $\begin{array}{l}\text { Урус-Мартан (Катыр-Юрт, Гехи), Курчалой (Цоцин-Юрт, Автуры, } \\
\text { Гелдаган, Майртуп), Гудермес, Шали (Герменчук), Аргун (Мескер-Юрт), } \\
\text { Бачи-Юрт (Аллерой), Ойсхара, Алхан-Кала (Алхан- Юрт), Старые Атаги, } \\
\text { Ачхой-Мартан, Гойты, Самашки, Дуба-Юрт, Серноводское, Махкеты, } \\
\text { Толстой-Юрт, Ассиновская, Червленная }\end{array}$ \\
\hline 20 & Махачкала & 1016 & 1105 & 8,3 & 10,7 & 8,8 & Буйнакск (Нижнее Казанище), Карабудахкент, Манас, Нижний Дженгутай \\
\hline 21 & Пятигорск & 1072 & 1081 & 1,7 & 0,6 & 0,8 & $\begin{array}{l}\text { Кисловодск, Ессентуки (Ессентукская), Георгиевск (Незлобная, } \\
\text { Краснокумское), Минеральные Воды, Учкекен, Иноземцево, }\end{array}$ \\
\hline
\end{tabular}

${ }^{71}$ Кроме микрорайона Донской (входит в УА Кривянская). 
Железноводск, Новопавловск, Суворовская, Залукокоаже, Малка, Александрийская, Лысогорская

\begin{tabular}{ll}
\multicolumn{2}{c}{19 МА-миллиоников } \\
\hline 22 & Новокузнецк - Прокопьевск \\
23 & Владикавказ - Назрань \\
24 & Набережные Челны \\
25 & Тюмень \\
26 & Барнаул \\
27 & Тольятти \\
28 & Владивосток \\
29 & Ижевск \\
30 & Калининград \\
31 & Томск \\
32 & Чебоксары \\
33 & Ульяновск \\
34 & Ярославль \\
35 & Астрахань \\
36 & Пенза \\
37 & Киров \\
38 & Тула \\
39 & Хабаровск \\
40 & Оренбург \\
41 & Кемерово \\
42 & Белгород \\
43 & Липецк \\
44 & Симферополь $* *$ \\
45 & Рязань \\
46 & Ставрополь \\
47 & Иваново \\
48 & Курск \\
49 & Брянск \\
50 & Архангельск \\
\cline { 2 - 2 } & \\
\hline
\end{tabular}

1034
930
913
721
828
834
785
759
701
724
743
771
746
721
714
694
754
677
656
678
634
667
664
631
571
661
605
641
613

285
9
9
9
8
8
8
7
7
785
782
778
771
741
730
724
724
720
707
699
686
675
667
650
650
648
640
622
597

${ }^{72}$ Кроме микрорайона Яблоневый Овраг.

Прокопьевск *, Новоильинский (район Новокузнецка), Осинники

(Калтан), Красный Камень (микрорайон Киселёвска), Краснобродский Назрань *, Беслан, Кантышево, Алагир, Нестеровская, Ардон, Верхние

Ачалуки, Сурхахи, Гизель, Дигора

Нижнекамск, Елабуга, Менделеевск

Боровский, Винзили, Богандинский

Новоалтайск, Сибирский

Жигулёвск ${ }^{72}$, Ягодное

Заводской (мкрн. Артёма), Раздольное

Агрыз, Завьялово

Балтийск, Пионерский (Светлогорск), Светлый, Зеленоградск, Гвардейск

Северск, Богашево, Светлый

Цивильск

Новоульяновск, Чердаклы

Тутаев, Гаврилов-Ям

Красный Яр, Камызяк, Нариманов, Володарский

Заречный, Мокшан

Кирово-Чепецк, Слободской, Лянгасово (микрорайон Кирова)

Ясногорск, Советск, Болохово

Подгородняя Покровка

Березовский, Топки, Лесная Поляна (микрорайон Кемерово), Кедровка (микрорайон Кемерово)

8,3 Шебекино, Строитель, Борисовка, Томаровка, Октябрьский

1,1 Грязи

0,4 Бахчисарай, Белогорск, Октябрьское, Почтовое, Зуя, Кольчугино

$\begin{array}{ll}13,7 & \text { Пелагиада, Рыздвяный } \\ -1,9 & \text { Шуя, Фурманов, Тейково }\end{array}$

5,7 Курчатов

$-3,0$ Дятьково, Карачев, Фокино, Сельцо

$\begin{array}{ll}-3,0 & \text { Дятьково, Карачев, Фокино, } \\ -2,6 & \text { Северодвинск, Новодвинск }\end{array}$ 


\begin{tabular}{|c|c|c|c|c|c|c|c|}
\hline 51 & Стерлитамак & 592 & 584 & 3,1 & $-5,5$ & $-1,3$ & Салават, Ишимбай \\
\hline 52 & Нальчик & 573 & 583 & $-0,4$ & 4,2 & 1,8 & $\begin{array}{l}\text { Баксан (Дыгулыбгей, Исламей, Заюково), Нарткала, Чегем (Чегем } \\
\text { Второй), Старый Черек, Анзорей }\end{array}$ \\
\hline 53 & Хасавюрт & 502 & 575 & 11,8 & 15,6 & 14,4 & $\begin{array}{l}\text { Кизилюрт, Дылым (Ленинаул), Герзель-Аул, Муцалаул, Костек, Ножай- } \\
\text { Юрт, Стальское, Новогагатли, Мескеты }\end{array}$ \\
\hline 54 & Улан-Удэ & 465 & 533 & 14,5 & 14,8 & 14,5 & Онохой \\
\hline 55 & Сочи & 421 & 530 & 25,7 & 26,5 & 26,1 & районы города Сочи: Адлер, Лазаревское, Лоо \\
\hline 56 & Шахты & 558 & 525 & $-4,4$ & $-7,3$ & $-5,9$ & Новошахтинск, Гуково, Красный Сулин, Зверево \\
\hline 57 & Владимир & 508 & 509 & 3,4 & $-5,8$ & 0,3 & $\begin{array}{l}\text { Радужный, Юрьевец + Энергетик (микрорайоны Владимира) Собинка, } \\
\text { Судогда, Лакинск, Суздаль }\end{array}$ \\
\hline 58 & Тамбов & 502 & 501 & 4,2 & $-8,1$ & $-0,1$ & Котовск, Рассказово \\
\hline 59 & Тверь & 481 & 500 & 5,1 & $-4,8$ & 3,9 & Редкино \\
\hline & 38 МА-полумиллиоников & 25671 & 26799 & 5,7 & 1,0 & 4,4 & \\
\hline Ито & о по 59 крупным МА & 76705 & 82114 & 8,4 & 2,7 & 7,1 & \\
\hline $\mathrm{Oct}$ & льное население РФ ** & 68496 & 64635 & & & $-5,6$ & \\
\hline \multicolumn{8}{|c|}{ Справочно: Прочие МА численностью не менее 250 тыс. человек, входящие в ОМА не менее 500 тыс. человек: } \\
\hline & Саранск & 466 & 482 & 7,7 & $-7,0$ & 3,3 & Рузаевка, Ромоданово \\
\hline & Севастополь ** & 414 & 481 & 19,4 & 7,1 & 16,3 & районы Севастополя: Северная Сторона, Балаклава, Кача; Вилино \\
\hline & Калуга & 452 & 452 & 1,9 & $-5,4$ & $-0,1$ & Товарково, Воротынск, Кондрово \\
\hline & Орёл & 451 & 441 & $-1,8$ & $-4,2$ & $-2,2$ & Кромы, Нарышкино \\
\hline & Нижний Тагил & 460 & 441 & $-3,5$ & $-6,6$ & $-4,2$ & Верхняя Салда, Нижняя Салда \\
\hline & Новороссийск & 374 & 438 & 13,6 & 26,4 & 17,3 & Геленджик, Раевская \\
\hline & Новомосковск & 430 & 404 & $-6,4$ & $-5,5$ & $-6,0$ & $\begin{array}{l}\text { Киреевск, Богородицк, Кимовск, Сокольники (микрорайон } \\
\text { Новомосковска) }\end{array}$ \\
\hline & Смоленск & 386 & 403 & 4,8 & 3,8 & 4,7 & Гнёздово (микрорайон Смоленска) \\
\hline & Армавир & 348 & 347 & 0,0 & $-1,5$ & $-0,4$ & Успенское \\
\hline & Таганрог & 357 & 346 & $-2,5$ & $-6,1$ & $-3,1$ & Покровское, Матвеев Курган \\
\hline & Кострома & 327 & 339 & 3,2 & 5,7 & 3,5 & Красное-на-Волге \\
\hline
\end{tabular}

Источник: Расчеты автора на основе данных (Росстат 2010, 2020).

Примечания:

* - Состав УА указан в таблице П-2.

** - Расчеты проведены в том числе с использованием данных для населения Крыма и Севастополя: (Укрстат 2011). 


\section{Таблица П-4. Объединенные метрополитенские ареалы России численностью не менее 500 тыс. человек}

\begin{tabular}{|c|c|c|c|c|c|c|c|}
\hline \multirow[b]{2}{*}{ № } & \multirow{2}{*}{$\mathrm{OMA}^{73}$} & \multicolumn{2}{|c|}{$\begin{array}{c}\text { Население, } \\
\text { тыс. человек }\end{array}$} & \multicolumn{3}{|c|}{$\begin{array}{c}\text { Изменение численности населения, } \\
2020 \text { г. к } 2010 \text { г., \% }\end{array}$} & \multirow{2}{*}{$\begin{array}{c}\text { Состав ОМА: } \\
\text { MA, входящие в состав } \mathrm{OMA}^{74}\end{array}$} \\
\hline & & 2010 г. & 2020 г. & $\begin{array}{l}\text { основной } \\
\text { МА }\end{array}$ & прочие МА & OMA & \\
\hline 1 & Москва - Электросталь & 18953 & 20720 & 9,7 & $-8,8$ & 9,3 & $\begin{array}{l}\text { Дубна (Кимры), Александров + Струнино (Карабаново) }{ }^{75}, \text { Конаково, } \\
\text { Волоколамск, Петушки, Талдом, Новозавидовский }\end{array}$ \\
\hline \multirow[t]{2}{*}{2} & Санкт-Петербург & 5832 & 6556 & 12,6 & 2,0 & 12,4 & Сосновый Бор, Любань, Каменка \\
\hline & Москва и Санкт-Петербург & 24785 & 27276 & 10,4 & $-6,8$ & 10,1 & \\
\hline 3 & $\begin{array}{l}\text { Ростов-на-Дону - Шахты - } \\
\text { Таганрог }\end{array}$ & 2810 & 2853 & 5,3 & $-4,8$ & 1,5 & Шахты *, Таганрог *, Кущевская, Зерноград, Багаевская \\
\hline 4 & Самара - Тольятти & 2448 & 2466 & 1,3 & $-0,3$ & 0,7 & Тольятти *, Безенчук \\
\hline 5 & Екатеринбург & 2208 & 2357 & 8,2 & $-7,2$ & 6,7 & Новоуральск (Верхний Тагил), Асбест (Рефтинский, Малышева) \\
\hline 6 & Нижний Новгород & 2224 & 2204 & $-0,2$ & $-7,1$ & $-0,9$ & $\begin{array}{l}\text { Павлово (Ворсма), Мулино (Ильиногорск), Семенов, Дальнее } \\
\text { Константиново }\end{array}$ \\
\hline 7 & Краснодар & 1870 & 2130 & 20,3 & 2,0 & 13,9 & $\begin{array}{l}\text { Славянск-на-Кубани (Полтавская, Петровская, Анастасиевская, } \\
\text { Старонижестеблиевская), Усть-Лабинск (Ладожская), Тимашевск } \\
\text { (Брюховецкая), Кореновск (Платнировская), Горячий Ключ, } \\
\text { Калининская + Старовеличковская, Мингрельская }\end{array}$ \\
\hline 8 & Новосибирск & 1927 & 2121 & 10,2 & $-4,1$ & 10,1 & Горный \\
\hline 9 & Махачкала & 1642 & 1813 & 8,8 & 13,0 & 10,4 & Хасавюрт *, Избербаш (Каякент), Сергокала \\
\hline 10 & Казань & 1542 & 1696 & 10,4 & $-1,2$ & 10,0 & Арск, Звенигово \\
\hline 11 & Челябинск & 1560 & 1646 & 5,6 & 1,0 & 5,5 & Кунашак \\
\hline 12 & Волгоград - Волжский & 1592 & 1572 & $-1,0$ & $-12,7$ & $-1,3$ & Калач-на-Дону \\
\hline 13 & Уфа & 1317 & 1435 & 9,1 & $-1,2$ & 9,0 & Кушнаренково \\
\hline 14 & Воронеж & 1327 & 1419 & 7,7 & $-4,8$ & 6,9 & Усмань, Хлевное, Верхняя Хава, Нижнедевицк \\
\hline 15 & Ярославль - Кострома & 1379 & 1392 & 3,3 & $-1,8$ & 1,0 & Кострома *, Рыбинск, Ростов \\
\hline 16 & $\begin{array}{l}\text { Симферополь - } \\
\text { Севастополь ** }\end{array}$ & 1298 & 1366 & 0,4 & 10,4 & 5,3 & Севастополь *, Евпатория (Саки) \\
\hline 17 & Красноярск & 1224 & 1366 & 11,7 & нет & 11,7 & \\
\hline
\end{tabular}

73 Указан главный город и УА свыше 250 тыс. человек.

${ }^{74}$ В скобках указаны населенные пункты и УА свыше 10 тыс. человек, входящие в соответствующий МА, не указанные в таблицах П-2 и П-3.

75 Здесь и далее через знак «+» обозначены иные населенные пункты численностью свыше 10 тыс. человек, входящие в этот УА. 


\begin{tabular}{|c|c|c|c|c|c|c|c|}
\hline 18 & Омск & 1351 & 1359 & 0,6 & нет & 0,6 & \\
\hline 19 & Пермь & 1271 & 1347 & 6,7 & $-5,4$ & 5,9 & Добрянка, Нытва, Оханск \\
\hline 20 & Саратов & 1304 & 1327 & 2,3 & $-5,8$ & 1,7 & Маркс, Красноармейск, Подлесное \\
\hline 21 & Тула - Новомосковск & 1308 & 1246 & $-4,0$ & $-5,8$ & $-4,7$ & Новомосковск *, Алексин, Плавск, Венев \\
\hline 22 & Грозный & 1066 & 1241 & 16,8 & 11,7 & 16,5 & Ведено, Калиновская, Шатой, Ялхой-Мохк \\
\hline 23 & Иркутск & 1100 & 1177 & 7,1 & $-6,6$ & 7,0 & Мишелевка \\
\hline 24 & Ижевск & 1116 & 1142 & 4,6 & $-2,5$ & 2,3 & Воткинск, Сарапул, Чайковский \\
\hline 25 & Пятигорск & 1133 & 1138 & 0,8 & $-6,0$ & 0,5 & Зеленокумск \\
\hline 26 & $\begin{array}{l}\text { Новокузнецк - } \\
\text { Прокопьевск }\end{array}$ & 1181 & 1135 & $-3,8$ & $-5,4$ & $-4,0$ & Междуреченск (Мыски) \\
\hline 27 & Владивосток & 1091 & 1118 & 2,6 & 2,4 & 2,5 & Уссурийск, Большой Камень (Фокино) \\
\hline 28 & Владикавказ - Назрань & 998 & 1074 & 6,6 & 22,0 & 7,7 & Малгобек + Сагопши \\
\hline 29 & Набережные Челны & 1006 & 1037 & 3,9 & $-5,4$ & 3,1 & Заинск, Мензелинск, Камские Поляны \\
\hline \multicolumn{2}{|r|}{27 ОМА-миллиоников } & 40293 & 42178 & 5,6 & 0,3 & 4,7 & \\
\hline 30 & Новороссийск & 819 & 959 & 17,3 & 16,9 & 17,1 & $\begin{array}{l}\text { Крымск (Ахтырский + Холмская, Абинск), Анапа + Анапская + } \\
\text { Витязево (Гостагаевская), Темрюк (Старотитаровская), } \\
\text { Варениковская }\end{array}$ \\
\hline 31 & Тюмень & 733 & 954 & 30,8 & $-12,2$ & 30,1 & Тугулым \\
\hline 32 & Ставрополь & 873 & 938 & 13,7 & $-4,5$ & 7,4 & $\begin{array}{l}\text { Невинномысск (Кочубеевское), Изобильный (Солнечнодольск, } \\
\text { Донское) }\end{array}$ \\
\hline 33 & Барнаул & 848 & 884 & 4,5 & $-6,4$ & 4,2 & Павловск \\
\hline 34 & Нальчик & 801 & 810 & 1,8 & $-0,8$ & 1,0 & Прохладный (Майский, Карагач), Терек (Эльхотово), Советская \\
\hline 35 & Калининград & 712 & 800 & 12,6 & $-1,7$ & 12,3 & Правдинск \\
\hline 36 & Чебоксары & 754 & 792 & 5,3 & $-11,5$ & 5,0 & Красноармейское \\
\hline 37 & Ульяновск & 782 & 788 & 0,9 & $-7,5$ & 0,7 & Старая Майна \\
\hline 38 & Томск & 724 & 784 & 8,4 & нет & 8,4 & \\
\hline 39 & Пенза & 742 & 754 & 2,2 & $-13,1$ & 1,6 & Сурск, Лунино \\
\hline 40 & Липецк & 753 & 751 & 1,1 & $-11,0$ & $-0,3$ & Лебедянь, Данков, Лев Толстой \\
\hline 41 & Хабаровск & 705 & 745 & 6,4 & $-13,0$ & 5,6 & Хор (Переяславка) \\
\hline 42 & Астрахань & 721 & 741 & 2,8 & нет & 2,8 & \\
\hline 43 & Киров & 708 & 737 & 4,4 & $-6,7$ & 4,2 & Юрья \\
\hline 44 & Белгород & 680 & 730 & 8,3 & $-4,7$ & 7,4 & Короча, Прохоровка \\
\hline 45 & Курск & 696 & 718 & 5,7 & $-13,2$ & 3,2 & Льгов, Обоянь, Щигры \\
\hline 46 & Оренбург & 656 & 707 & 7,8 & нет & 7,8 & \\
\hline 47 & Иваново & 719 & 702 & $-1,9$ & $-8,0$ & $-2,4$ & Приволжск (Волгореченск), Комсомольск \\
\hline 48 & Владимир & 711 & 700 & 0,3 & $-6,2$ & $-1,5$ & Ковров (Камешково) \\
\hline 49 & Кемерово & 678 & 699 & 3,1 & нет & 3,1 & \\
\hline
\end{tabular}




\begin{tabular}{|c|c|c|c|c|c|c|c|}
\hline 50 & Рязань & 653 & 670 & 3,0 & $-9,0$ & 2,6 & Спасск-Рязанский, Старожилово \\
\hline 51 & Брянск & 641 & 622 & $-3,0$ & нет & $-3,0$ & \\
\hline 52 & Армавир & 628 & 620 & $-0,4$ & $-2,6$ & $-1,4$ & Лабинск (Курганинск, Мостовской), Хакуринохабль \\
\hline 53 & Архангельск & 613 & 597 & $-2,6$ & нет & $-2,6$ & \\
\hline 54 & Стерлитамак & 603 & 594 & $-1,3$ & $-7,0$ & $-1,4$ & Стерлибашево \\
\hline 55 & Нижний Тагил & 599 & 568 & $-4,2$ & $-8,5$ & $-5,2$ & Кушва (Красноуральск), Невьянск (Кировград) \\
\hline 56 & Тверь & 548 & 562 & 3,9 & $-6,5$ & 2,6 & Торжок \\
\hline 57 & Саранск & 552 & 560 & 3,3 & $-9,4$ & 1,3 & Чамзинка, Починки, Кемля, Большие Березники \\
\hline 58 & Смоленск & 553 & 554 & 4,7 & $-9,9$ & 0,2 & Сафоново (Верхнеднепровский, Дорогобуж), Ярцево, Починок \\
\hline 59 & Улан-Удэ & 465 & 533 & 14,5 & нет & 14,5 & \\
\hline 60 & Сочи & 421 & 530 & 26,1 & нет & 26,1 & \\
\hline 61 & Орёл & 536 & 516 & $-2,2$ & $-11,3$ & $-3,7$ & Мценск, Болхов, Чернь \\
\hline 62 & Тамбов & 513 & 510 & $-0,1$ & $-17,6$ & $-0,5$ & Сатинка \\
\hline 63 & Калуга & 504 & 500 & $-0,1$ & $-7,3$ & $-0,8$ & Суворов, Медынь \\
\hline \multicolumn{2}{|r|}{38 ОМА-полумиллиоников } & 22645 & 23629 & 5,2 & $-2,4$ & 4,3 & \\
\hline \multicolumn{2}{|c|}{ Итого по 63 крупным ОМА } & 87723 & 93084 & 7,0 & $-0,8$ & 6,1 & \\
\hline \multicolumn{2}{|c|}{ Остальное население РФ ** } & 57478 & 53665 & & & $-6,6$ & \\
\hline
\end{tabular}

Источник: Расчеты автора на основе данных (Росстат 2010, 2020).

Примечание: *-Состав МА указан в таблицах П-2 и П-3.

** - Расчеты проведены в том числе с использованием данных для населения Крыма и Севастополя: (Укрстат 2011). 


\title{
DEFINING THE BOUNDARIES OF URBAN AGGLOMERATIONS IN RUSSIA: MODEL CREATION AND RESULTS
}

\section{ALEXANDER RAYSIKH}

\begin{abstract}
The article is a continuation of the article (Raysikh 2020), where the problem of defining the boundaries of urban agglomerations or delineating urban agglomerations based on world experience was formulated. At the same time, it was emphasized that the methodology for assessing the boundaries of urban agglomerations should be based, on the one hand, on the source data available to all countries, and, on the other hand, on accumulated world experience, ensuring an acceptable approximation to many already used models of delimitation.

The purpose of this article is to develop and test a model of the delimitation of urban agglomerations based on international and domestic experience and suitable for the conditions of Russia and other countries of the world.

Based on the available data, the results of using various methods of urban agglomeration delimitation were analyzed, and their advantages and disadvantages were identified. As a result, the author's model of urban agglomeration delimitation was proposed. The assessment of the composition and boundaries of urban agglomerations in Russia made on this basis showed a fairly high degree of approximation to existing models of urban agglomeration delimitation (which, as a rule, are based on the use of raw data that are not evaluated by statistical agencies in most countries of the world, including Russia).
\end{abstract}

Key words: urban agglomeration, delimitation of urban agglomerations, agglomeration core, urbanized area, metropolitan area, combined metropolitan area.

AleXander RaysikH (reisig@mail.ru), InDEPENDENT EXPERT, Russia.

DATE RECEIVED : MAY 2020.

\section{REFERENCES}

Antonov E.V., Makhrova A.G. (2019). The Largest urban agglomerations and forms of settlement of the superaglomerational level in Russia. Izvestiya RAN [Izvestiya RAS]. Geographical series, 4, 31-45. (In Russ.) URL: https://elibrary.ru/item.asp?id=39239323

Izhguzina N.R. (2014) Approaches to the delimitation of urban agglomerations. Diskussiya [Discussion], 9(50), 44-52. (In Russ.). Retrieved from https://cyberleninka.ru/article/v/podhody-k-delimitatsii-gorodskih-aglomeratsiy

Lappo G.M. (1978). Development of urban agglomerations in the USSR. Moscow: Nauka. (In Russ.).

Lappo G.M., Polyan P.M., Selivanova T.V. (2007). Agglomerations in Russia in the 21st century. Vestnik Fonda regional'nogo razvitiya Irkutskoi oblasti [Bulletin of the regional development Fund of Irkutsk region], 1, 45-52, (In Russ.). Retrieved from http://www.frrio.ru/uploads_files/Lappo.pdf

Leyzerovich E.E. (2010). Grid of economic microdistricts in Russia. 2008 version. Regional 'nye issledovaniya [Regional study]. 4(30), 14-28. (In Russ.). Retrieved from https://elibrary.ru/item.asp?id=15637765 
Limonov L.E. (2014). Regional'naya ekonomika i prostranstvennoye razvitiye [Regional economy and spatial development]. Vol. 1. Moscow: Urait. (In Russ.).

Listengurt F.M. (1975). Criteria for the allocation of large-scale agglomerations in the USSR. Izvestiya Akademii nauk USSR [News of the Academy of Sciences], geographical series, 6, 41-50. (In Russ.).

Makhrova A.G., Babkin R.A. (2018). Analysis of Moscow agglomeration settlement system pulsations based mobile operators data. Regional'nyye issledovaniya [Regional studies], 2(60), Smolensk state University, 68-78. (In Russ.). Retrieved from https://elibrary.ru/item.asp?id=35417472

Maloyan G.A. (2012). To the problems of forming urban agglomerations. Arkhitektura i stroitel'stvo Rossii [Architecture and construction of Russia], 2, 83-85. (In Russ.). Retrieved from https://cyberleninka.ru/article/n/k-problemam-formirovaniya-gorodskih-aglomeratsiy

Min ekonomrazvitiya (2018). Supporting materials for the draft spatial development Strategy for the period up to 2025. Appendix to the letter of the Ministry of economic development of Russia dated 27.07.2018 No. 21077-vzh/D27i. (In Russ.). Retrieved from https://www.spsss.ru/assets/files/2018/v-nts_strategiya-prostranstvennogo-razvitiya.pdf

Monastyrskaya M.E., Peslyak O.A. (2019). The method of determining the boundaries of urban agglomerations. Vestnik BGTU im. V.G. Shukhova [Bulletin of BSTU named after V.G. Shukhov], 2, 111-121. (In Russ.). Retrieved from https://riorpub.com/en/storage/view/31904

Nefedova T.G., Averkieva K.V., Makhrova A.G. (Red.) (2016). Mezhdu domom i ... domom. Vozvratnaya prostranstvennaya mobil`nost` naseleniya Rossii [Between home and ... home. Return spatial mobility of the Russian population]. Moscow: New Chronograph. (In Russ.).

Pivovarov Yu.L. (2002). Constriction of the 'economic oecumene' of Russia. Mirovaya ekonomika i mezhdunarodnye otnosheniya [World Economy and International Relations], 4, 63-69. (In Russ.).

Polyan P.M. (2014). Territorial structures - urbanization - settlement: theoretical approaches and research methods. Moscow: Novy Chronograph. (In Russ.).

Polyan P.M., Zaslavsky I.N., Naimark N.I. (1988) .Problems of urban agglomerations delimitation: comparison and synthesis of leading methods. Problemy territorial `noj organizacii prostranstva i rasseleniya $\mathrm{v}$ urbanizirovannykh rajonakh [Problems of territorial organization of space and settlement in urbanized areas]. Sverdlovsk, 26-40. (In Russ.).

Puzanov A., Popov R. (2017). Approaches to assessing the development of urban agglomerations. Moscow: Institut ekonomiki goroda. (In Russ.) Retrieved from http://www.urbaneconomics.ru/sites/default/files/iue_press.pdf

Raysikh A.E. (2020). K voprosu ob opredelenii granits gorodskikh aglomeratsiy: mirovoy opyt i formulirovka problemy [Defining the boundaries of urban agglomerations: problems, international experience, solutions and results]. Demographic Review, 7(1), 27-53. (In Russ.). Retrieved from https://demreview.hse.ru/article/view/10819/12136

Rosstat (2010). Publication of the results of the 2010 all-Russian census. Vol. 1. The number and location of the population. 11. Population of Russia, Federal districts, subjects of the Russian Federation, urban districts, municipal districts, urban and rural settlements. (In Russ.). Retrieved from https://gks.ru/free_doc/new_site/perepis2010/croc/Documents/Vol1/pub-0111.xlsx

Rosstat (2019). Population of the Russian Federation by municipalities as of January 1, 2019, table 26-19. (In Russ.). Retrieved from https://www.gks.ru/compendium/document/13282. 
Rosstat (2020). The permanent population of the Russian Federation by municipality as of January 1, 2020. URL: https://gks.ru/folder/12781 (Information section, Operational information subsection).

Shitova Yu.Yu., Shitov Yu.A. (2016). GIS - monitoring of pendulum labor migration as a task of regional management. Sovremennye tekhnologii upravleniya [Modern control technologies], 2 (62), 49-60. (In Russ.). Retrieved from https://elibrary.ru/item.asp?id=25512255

Shitova Yu.Yu., Shitov Yu.A., Vlasov D.N. (2019). Digital monitoring of transport in the Moscow agglomeration using geoinformation systems. Vestnik Universiteta Pravitel`stva Moskvy [Bulletin of the Moscow Government University], 3 (45), 54-59. (In Russ.). Retrieved from https://elibrary.ru/item.asp?id=41192517

Sokolov S.N. (2015). Agglomeration forms of resettlement in Ugra. Aktual'nye problemy gumanitarnykh i estestvennykh nauk [Actual Problems of Humanitarian and Natural Sciences], 12-8, 61-66. (In Russ.). Retrieved from https://elibrary.ru/item.asp?id=25284020

Strel'nikov A.I., Semenova O.S. (2010). Options to identify the boundaries of agglomerations in modern terms based on the analysis of social and economic linkages and using calculation models. Transportnoe delo Rossii [Transport Business of Russia], 8(81), 145-155. (In Russ.). Retrieved from https://elibrary.ru/item.asp?id=20137326

Ukrstat (2011). Statistical collection "the number of available population of Ukraine as of January 1, 2011". Kiev: DKS. Retrieved from http://database.ukrcensus.gov.ua/PXWEB2007/ukr/publ_new1/2011/chnas.zip

Ulyaeva A.G. (2016). Development and approbation methods of determining the spatial localization of agglomeration (on materials of Republic Bashkortostan). Sovremennaya nauka: aktual'nyye problemy teorii i praktiki. Seriya: ekonomika i pravo [Modern science: actual problems of theory and practice. Series: Economics and law], 10, 48-54. (In Russ.). Retrieved from http://www.nauteh-journal.ru/files/74030711-81c9-405a-9ef7-c2cf65b992cb

Ulyaeva A.G., Migranova L.I. (2017). A Study of the process of circular labor migration in the urban agglomeration. Vestnik Belgorodskogo universiteta kooperacii, ekonomiki i prava [Bulletin of the Belgorod University of cooperation, economics and law], 5 (66), 179-193. (In Russ.). Retrieved from https://www.elibrary.ru/item.asp?id=29962579

Yusin G.S., Raev Yu.V., Alekseeva A.A. (2015). Improving the settlement system is a key direction of the spatial development strategy of Russia. Gradostroitel 'stvo [Urban planning], 2, 9-28. (In Russ.). Retrieved from https://elibrary.ru/item.asp?id=24373787

Zanadvorov V.S., Zanadvorova A.V. (2003). Ekonomika goroda. Vvodnyy kurs: uchebnoye posobiye [The Economy of the city. Introductory course: tutorial]. Moscow: ICC «Akademkniga. (In Russ.) 